Pequenas plantas, grandes estratégias:

adaptações e sobrevivência no Cerrado

Aelton Biasi Giroldo 


\title{
Pequenas plantas, grandes estratégias: adaptações e sobrevivência no Cerrado
}

\author{
Aelton Biasi Giroldo
}

Orientador Dr. Aldicir Scariot

Tese apresentada ao Departamento de PósGraduação em Ecologia, da Universidade de Brasília, como pré-requisito para obtenção do Grau de Doutor em Ecologia.

Brasília, DF 
Ficha Catalográfica

\begin{tabular}{|ll|}
\hline BAE248 & Giroldo, Aelton Biasi \\
$\mathrm{p}$ & Pequenas plantas, grandes estratégias: adaptações e \\
& sobrevivência no Cerrado / Aelton Biasi Giroldo; orientador \\
& Aldicir Scariot. - Brasília, 2016. \\
xi+51 p. & \\
& Tese (Doutorado - Doutorado em Ecologia) - \\
Departamento de Pós-Graduação em Ecologia - \\
Universidade de Brasília, 2016. \\
\\
1. Ecofisiologia. 2. Adaptações a ambientes pirofíticos. 3. \\
Evolução savana. 4. Relações competititvas. 5. Reprodução \\
pós-fogo. I. Scariot, Aldicir, orient. II. Título.
\end{tabular}


Aelton Biasi Giroldo

\section{Pequenas plantas, grandes estratégias: adaptações e sobrevivência no Cerrado}

Banca Examinadora:
Dr. Aldicir O. Scariot
Presidente / Orientador
Embrapa - Cenargen

Dr. Marcelo F. Simon

Membro Titular

Embrapa - Cenargen

Dr. Fabian Borghetti

Membro Titular

UnB
Dra. Alessandra T. Fidelis

Membro Titular

UNESP - Rio Claro

Dra. Heloísa S. Miranda

Membro Titular

UnB

Dr. Eduardo R. M. Barbosa

Membro Suplente

UnB

Brasília, DF

Agosto de 2016 


\section{Agradecimentos}

Este trabalho foi desenvolvido com apoio de muitas instituições e pessoas, que contribuíram com material, intelecto e recursos.

Inicio agradecendo àqueles que financiaram este projeto: à CAPES, que forneceu minha bolsa de estudo no início do presente doutorado e também a bolsa de doutorado sanduíche (Processo número 99999.009939/2014-08); ao CNPq, que forneceu bolsa na parte final do curso, juntamente com uma taxa de bancada que me permitiu a aquisição de enzimas e material de laboratório utilizado neste projeto; ao Funbio/TFCA, que forneceu parte dos recursos utilizados em laboratório; à Embrapa Recursos Genéticos e Biotecnologia, que forneceu veículos, casa da vegetação, e laboratório para a execução deste trabalho.

Agradeço ao meu orientador Dr. Aldicir Scariot, por aceitar essa empreitada, que embora se distancie do seu foco de pesquisa, não me desincentivou no desenvolvimento do presente trabalho. Agradeço-o em especial ao apoio e ensinamentos.

Agradeço ao Dr. William Hoffmann (Bill) pela conversa inicial, pré-projeto, que me deu uma luz no que poderia ser feito de diferente. E principalmente pelo apoio, conversas e ensinamentos no período que passei na North Carolina State University.

Agradeço à banca examinadora por terem feito considerações valiosas, as quais engrandeceram em muito este trabalho, principalmente no que se refere ao acréscimo valioso às futuras publicações.

Agradeço ao amigo Dr. Bruno M. T. Walter que me ajudou desde a seleção de espécies para o desenvolvimento da tese, até a parte escrita e intelectual, principalmente no que diz ao capítulo 2. Agradeço pelas conversas à toa e filosóficas, pelos ensinamentos daquele que é um excelente professor, mas que não dá o braço a torcer.

Agradeço ao amigo Dr. Marcelo F. Simon que me guiou não só com boas conversas, mas com seus trabalhos que são base deste estudo. Agradeço-o não só pelos ensinamentos, mas também pelas sementes e identificação de espécies de Mimosoideae.

À amiga Juliana Benez que me ajudou em parte das coletas de dados de campo (capítulo 1 e 3), pelas conversas e risadas, meu muito obrigado!

Obrigado à amiga Ms. Pamela Moser pela ajuda na coleta de dados (capítulo 3), incentivo, discussões, conservas e risadas.

Agradeço também à amiga Dra. Klécia Massi que me ajudou na coleta dos dados do capítulo 2, pelas leituras indicadas, referências compartilhadas e boas conversas. 
Agradeço à amiga Dra. Isabela Lustz, por ter sido uma irmã, ter me ajudado no plantio, coleta de sementes, ter me incentivado, ter revisado os meus textos que muitas vezes estavam péssimos, pelas boas e gratificantes conversas.

Ao amigo Dr. João Bringel que muitas vezes conversou, contou piadas, coletou, identificou e me ensinou um pouquinho do campo das Asteraceae, muito obrigado.

Agradeço ao amigo Valdeci F. Gomes (Dudu), Juarez P. do Amaral, Aécio Amaral Santos e Nilton Ferreira Barbosa pela ajuda em campo, conversas, ensinamentos e piadas.

Agradeço ao João Benedito Pereira (Cheba) pela ajuda na identificação das espécies, ensinamento de identificação, paciência e ajuda em campo.

Agradeço ao Dr. Luciano Bianchetti pelas boas conversas, por ter ajudado com literatura referente à Orchidaceae.

Agradeço à Nadine Ralha pela ajuda na coleta de sementes utilizadas no capítulo 1.

Agradeço ao Henrique J. C. Moreira por indicar locais onde poderia encontrar espécies específicas que foram utilizadas nesta tese, e pelas fotos utilizadas no capítulo 2.

Agradeço à Joseane Padilha por me orientar nas dúvidas estatísticas.

Agradeço ao Dr. Augusto C. Franco e à Dra. Cristiane da Silva Ferreira pelos ensinamentos em ecofisiologia, por liberarem o laboratório de ecofisiologia vegetal onde realizei as análises, pelas conversas e dicas preciosas.

Agradeço ao Dr. Thomas C. R. Williams por ter parado muitas vezes o que estava fazendo para me ajudar com dúvidas no laboratório.

Agradeço à Dra. Antonieta Salomão e Dra. Dulce Alves pelas dicas em conservação de sementes e quebra de dormência.

Agradeço ao Thiago Batista Moreira pela valiosa ajuda nos procedimentos de laboratório.

Agradeço ao William Silva do Carmo pelas inúmeras vezes que me ajudou no laboratório, dicas valiosas de como realizar alguma análise.

Agradeço à Estela Reis Andrade pelas dicas de como executar algumas análises no laboratório.

Agradeço à técnica Juliana, departamento de genética - UnB, pela ajuda nas análises de laboratório, principalmente no que se refere ao preparo de tampões.

Agradeço à Dra. Talita S. Reis pelas inúmeras conversas, ajuda no trabalho e ensinamentos. 
Agradeço ao pessoal do herbário IBGE, em especial a Luciano de Lima Guimarães por ter fornecido uma planilha com os dados do herbário, que foram utilizados no capítulo 2.

Agradeço à Leila M. D. Camacho e a Dra. Marília Gaspar pelas dicas referentes a reservas em espécies de Cerrado.

Agradeço ao Dr. Francisco J. L. Aragão e à Mirella Pupo Santos pelo empréstimo do LCpro-SD (BioScientific Ltd.).

Agradeço à Dra. Juliana G. Rando pela identificação das espécies de Chamaecrista utilizadas no capítulo 1.

Ao amigo Daniel Chaves pelas dicas no plantio de espécies, boas conversas e ensinamentos.

Agradeço ao Dr. Jair E. Q. de Faria Júnior e à Dra. Carolyn E. B. Proença pela identificação das espécies de Eugenia utilizadas no capítulo 1.

Agradeço à Dra. Vânia C. R. Azevedo, Zilneide P. de Souza Amaral e Marco Antonio Ferreira por ceder o nitrogênio líquido e o liofilizador necessário para realização das análises.

Agradeço à amiga Laura S. Orioli e ao amigo Ebenézer B. Rodrigues pelas boas conversas e ajuda na coleta de dados na casa de vegetação.

Agradeço ao amigo Dr. Daniel Vieira pelas críticas e sugestões.

Agradeço ao amigo Dr. Djalma B. Silva pelo incentivo, pelas boas conversas e ensinamentos.

Agradeço ao amigo Glocimar Pereira Silva pela ajuda na identificação, conversas e ensinamentos.

Agradeço ao corpo técnico da Embrapa - Cenargen que deu manutenção na casa de vegetação, auxiliou no enchimento dos sacos para plantio de mudas, em especial a Alexandre Peron, José Erculano de Carvalho, Domingos Alves, Manoel C. G. de Oliveira, Geraldo B. Guedes e José Gilson Souza.

Agradeço ao pessoal do Assentamento Americana, Grão Mogol, MG, em especial à Maria Elei, Cido, Cristovino, João Altino, Mariana e Elias pela ajuda na coleta das sementes de A. humile utilizadas neste trabalho.

Agradeço ao Sr. José Maria de Mendonça pela ajuda na coleta de semente de $C$. oblongifolia utilizada neste trabalho.

Agradeço à amiga Gabriela S. Ribeiro pelas inúmeras conversas, ajuda em consultas de plantas no Herbário Elcen, ensinamentos de entrada de dados no sistema do herbário, e pelos inúmeros conselhos. 
Agradeço à amiga Dr. Andrielle C. Amaral Lopes pela ajuda na consulta no herbário Elcen.

Agradeço ao amigo Dr. Marcelo B. Medeiros pelas inúmeras conversas e conselhos.

Agradeço ao amigo Sergio E. Noronha pelas conversas, e por todos os ensinamentos em geoprocessamento.

Agradeço ao Dr. Michael Just pelas conversas no laboratório na NCSU, pela ajuda em scripts no $\mathrm{R}$, pelas discussões acadêmicas, pela revisão de parte do texto da tese.

Agradeço ao Wyatt Sanders pelas conversas, ensinamentos na savana americana, ajuda em parte do texto desta tese.

Agradeço ao Dr. Juli Pausas pela conversa e incentivo.

Agradeço aos amigos Leonardo Borges, Gustavo Mariano, Maxmiller Cardoso, Arthur P. Souza, Marco Túlio R. Furtado, Monique Alves e Gabriel Penido pelas boas conversas.

Agradeço aos amigos Rodrigo R. Cruvinel, Pedro B. Vanconcelos, Daniela Panza, Gustavo Paiva, Helena Lara, e Paulo pelas boas conversas, ajuda e incentivo.

Agradeço a minha família aos meus pais Antonio Giroldo e Maria Aparecida Biasi Giroldo, aos meus irmãos Catiele B. Giroldo e Márllen B. Giroldo pela paciência, apoio e incentivo.

Agradeço à minha mulher e amada Natália A. Perigolo pela paciência, ajuda na coleta de dados, compreensão, incentivo e apoio, sem você está tese seria bem mais sem graça.

A todos que me ajudaram de alguma forma com esse trabalho, meu sincero muito obrigado. 


\section{Apresentação}

A abundância e a diversidade do estrato herbáceo em formações savânicas chamam a atenção de qualquer observador mais atento. Estas formas de vida chegam a representar mais de $60 \%$ da diversidade do bioma Cerrado. A questão levantada neste trabalho é o porquê desta dominância. Estudos realizados com pares congenéricos verificaram as características ecofisiológicas que favoreceriam as espécies de savana em detrimento às espécies de floresta em ambientes com fogo, entretanto no que se refere à comparação entre formas de vida no ambiente savânico, pouco foi investigado. Utilizando a abordagem de pares congenéricos, no capítulo 1 deste trabalho, foram selecionados pares de subarbustos e árvores, que ocorrem nas formações savânicas do bioma Cerrado. Foram examinadas as diferenças na biomassa de sementes, germinação, sobrevivência, capacidade de rebrota, investimento em biomassa e na capacidade fotossintética entre os pares congenéricos, e se essas características eram filogeneticamente conservadas.

No capítulo 2, por meio de uma extensa revisão da literatura e checagem de dados de todos os herbários disponíveis no speciesLink, juntamente com os dados do herbário do IBGE, foi criada uma lista de todas as espécies capazes de se reproduzir após a passagem do fogo, tanto em formações savânicas quanto florestais. O interessante desta lista é que ela começa como um teste no speciesLink, e acaba por se tornar um grande trabalho. Utilizando a ajuda de especialistas, juntamente com o esforço de parceiros, todas as espécies foram catalogadas e seus nomes foram checados no site Flora do Brasil. Além disso, as espécies foram classificadas quanto ao habitat - de formações florestais ou savânicas, família botânica, síndromes de polinização, dispersão e forma de vida. Para testar as hipóteses de que as subarbustivas possuem maior capacidade reprodutiva após a passagem do fogo, se comparadas às árvores, foi necessário utilizar dados relativos à todas as espécies do bioma.

No capítulo 3, foi testado o efeito competitivo de gramíneas sobre pares congenéricos de subarbustos e árvores, e dos pares congenéricos entre si. Os resultados deste capítulo trazem à tona a importância da biodiversidade em atenuar as relações competitivas e ao mesmo tempo indica a importância do "root-gap" para o estabelecimento de árvores no bioma Cerrado.

Por fim, os principais resultados dos três capítulos foram consolidados em um resultado geral, no qual tentou-se explicar a dominância dos subarbustos nas savanas; a relação fogobiodiversidade-evolução, e a importância das políticas de manejo de fogo para a conservação da biodiversidade do bioma Cerrado.

O autor 


\section{Pequenas plantas, grandes estratégias: \\ adaptações e sobrevivência no Cerrado}

\section{Sumário}

Resumo Geral

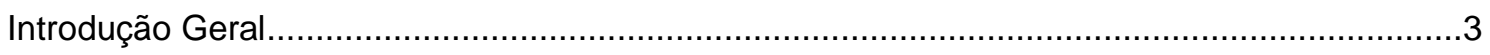

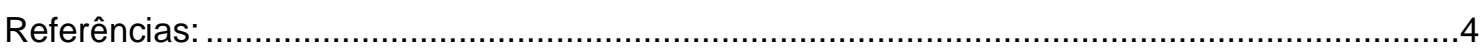

Small plants, great strategies: adaptations and survival of trees and subshrubs in a fire-prone

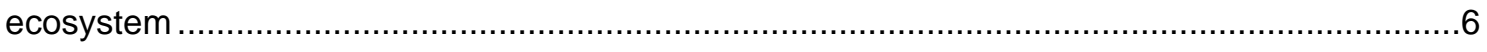

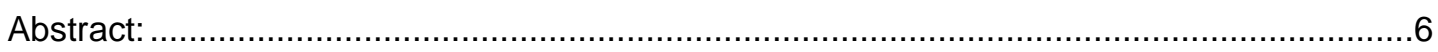

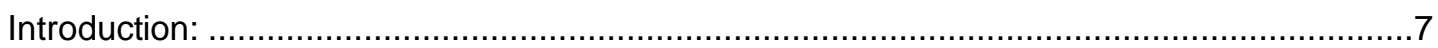

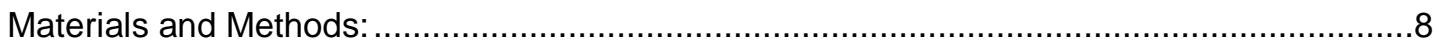

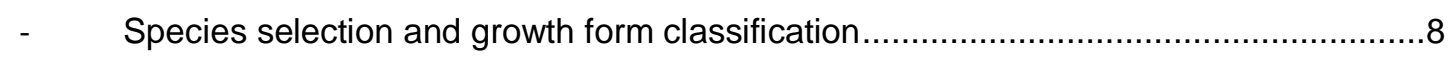

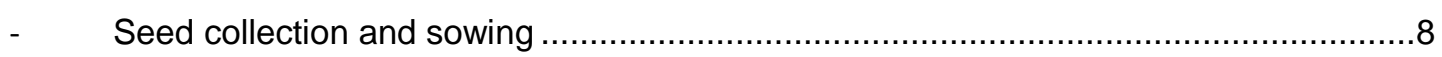

- $\quad$ Germination, survival, resprouting, biomass and reserves analysis ..........................10

- Photosynthesis, respiration and specific leaf area ..............................................10

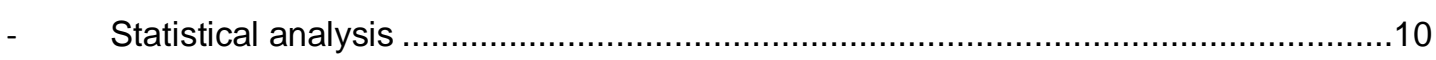

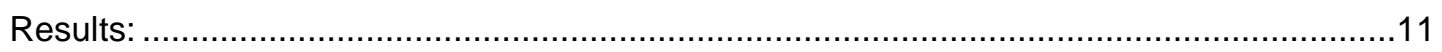

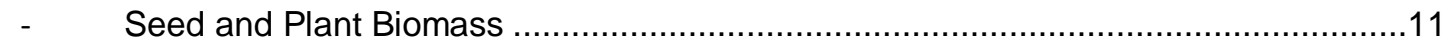

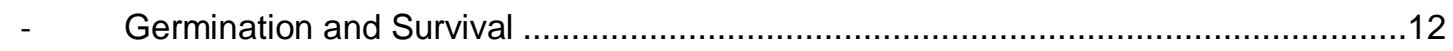

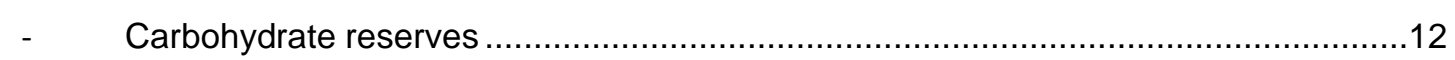

- $\quad$ Photosynthesis, Respiration and Specific Leaf Area (SLA) ....................................12

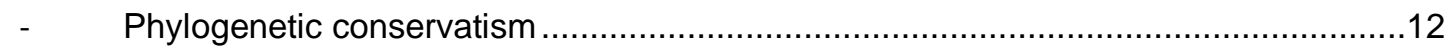

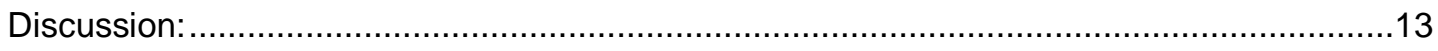

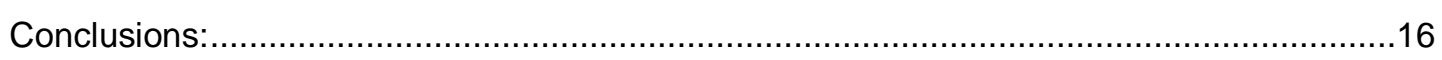

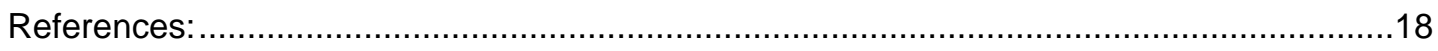

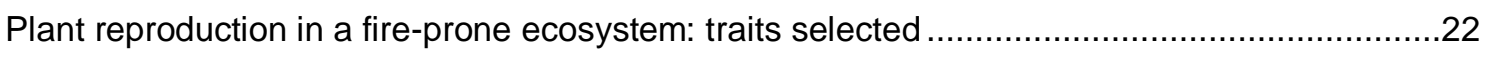

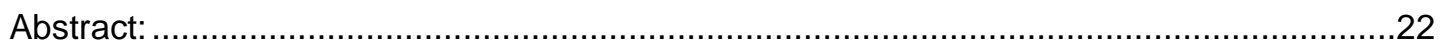

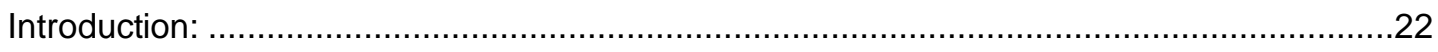

Able to reproduce after fire, stimulated by fire or fire-dependent flowering species: ............25

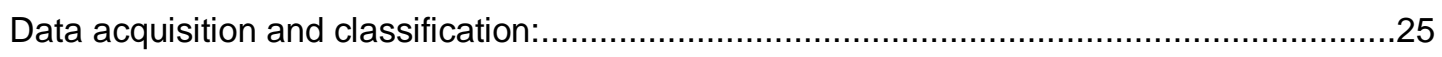

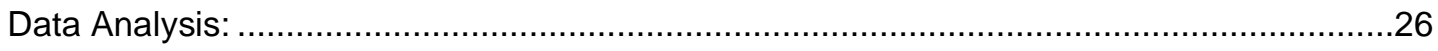

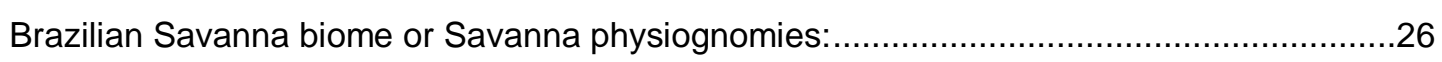

How many species can reproduce after a fire event? ......................................................27

Is reproduction between growth forms differentially influenced by fire? ..............................28

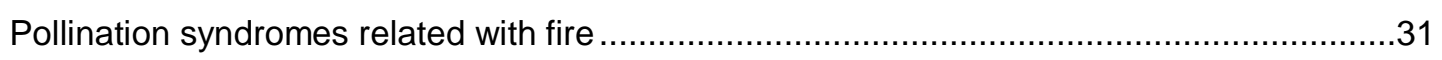

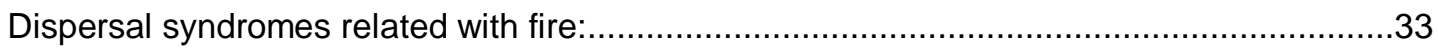

Conservation efforts in fire-prone ecosystems and general conclusions:............................35 
References:

Small plants, great strategies: a complex history about congeneric pairs and grass competition

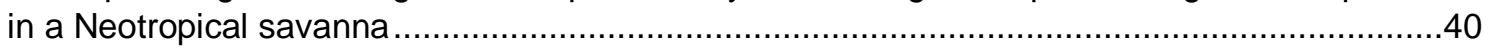

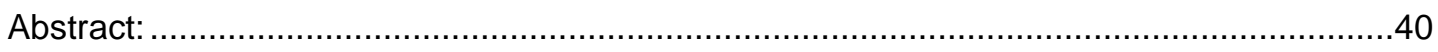

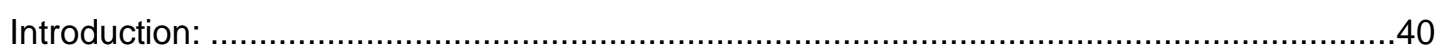

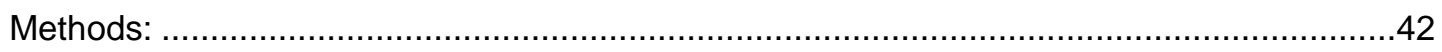

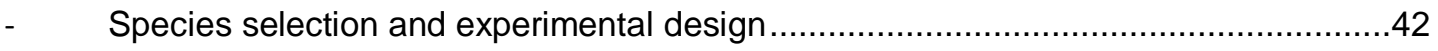

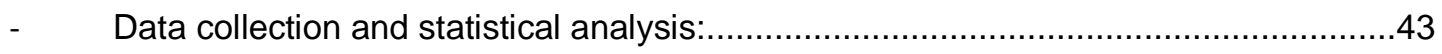

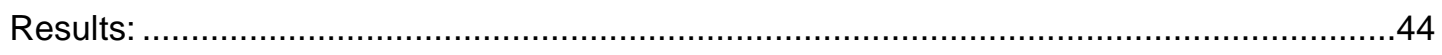

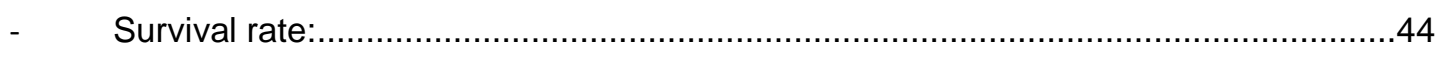

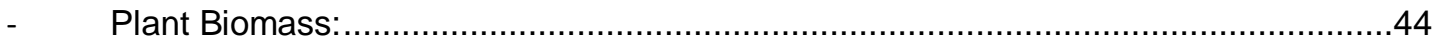

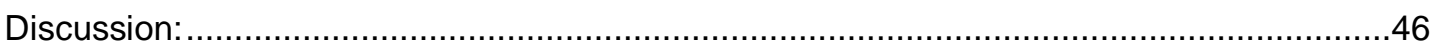

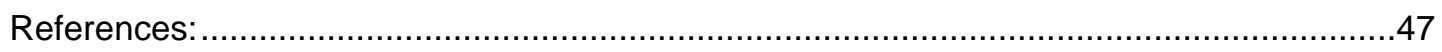

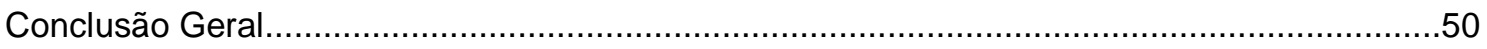




\section{Cerrado}

\section{Resumo Geral}

4 A diversificação da flora da savana brasileira ocorreu há $10 \mathrm{Ma}$, e envolveu a seleção de 5 características como casca espessa, desenvolvimento de órgãos subterrâneos, além de adaptações ecofisiológicas (ex. acúmulo de reservas, capacidade de rebrota) e redução das formas de vida. As formas de vida menores, como os subarbustos, representariam o extremo de adaptação a ambientes pirofíticos. Embora a biomassa aérea das formas de vida menores seja mais consumida durante a passagem de fogo do que das formas de vida maiores, como as árvores, elas hipoteticamente possuiriam mais reservas, maior capacidade fotossintética, além de se reproduzirem mais cedo e manterem a capacidade de rebrota por toda a vida. Embora esses argumentos tenham sido levantados como centrais para o sucesso das espécies subarbustivas em relação às arbóreas, nenhum estudo verificou a presença destas diferenças, com exceção das relações de fotossíntese. Em experimentos em casa de vegetação com pares congenéricos de subarbustos e árvores da savana brasileira, foram investigadas as diferenças no peso de sementes, germinação, sobrevivência, alocação de carbono estrutural e de reservas, capacidade de rebrota, capacidade competitiva e capacidade fotossintética. Por meio de revisão de literatura e checagem de dados em herbários foram verificadas as espécies capazes de se reproduzir após a passagem de fogo, verificando se alguma forma de vida é reprodutivamente favorecida após a passagem de fogo, além de verificar se alguma síndrome de dispersão e polinização se destaca em espécies que se reproduzem após o fogo.

Contrariando a hipótese levantada de que subarbustos representam o extremo evolutivo de adaptação ao bioma savânico, muitas das características verificadas se mostraram semelhantes entre árvores e subarbustos. Entretanto, as pequenas diferenças observadas poderiam se acumular ao longo da vida, culminando em histórias de vida bastante distintas quando no estágio adulto. Os subarbustos, de fato, investem menos em desenvolvimento aéreo e mais em armazenamento de energia na forma de reservas, além de possuírem um peso de sementes menor que as espécies arbóreas. Um total de 2058 espécies são capazes de se reproduzir após a passagem de fogo e, refutando a hipótese de supremacia reprodutiva dos subarbustos, foi encontrada que a razão de chance de uma árvore florescer após a passagem do fogo é maior que a de um subarbusto. Isso não significa que após o fogo um observador verá mais árvores florescendo, o que só aconteceria se a abundância das formas de vida fosse semelhante. O fogo não favorece nenhuma síndrome de polinização específica, mas favorece a dispersão zoocória em detrimento da autocórica. Quanto à capacidade competitiva, tanto subarbustos quanto árvores são prejudicados pela presença de gramíneas. Entretanto, a presença de árvores atenua as relações competitivas das gramíneas para os subarbustos, favorecendo-os. O oposto, entretanto, não é verdadeiro, e as árvores são, de forma sinérgica, negativamente afetadas pela 
efeito negativo no crescimento e sobrevivências das plantas subarbustivas, mas o contrário não é verdadeiro, e subarbustos não afetam o crescimento e sobrevivências das árvores.

41 A longa história evolutiva das plantas do Cerrado na presença do fogo selecionou diferentes 42 formas de vida, igualmente aptas a sobreviverem e reproduzirem neste ambiente. O grande 43 número de espécies capazes de se reproduzir após o fogo, distribuídas em diferentes famílias, 44 corrobora a ideia de que a aquisição de caracteres adaptativos para o fogo envolve simples 45 rearranjo de material genético e raramente mutações, o que norteia parte da hipótese de que o 46 fogo pode moldar as características funcionais de um ecossistema. A dominância dos 47 subarbustos (abundância e diversidade) pode ser explicada principalmente pela grande 48 quantidade de energia armazenada, o que favoreceria a sua sobrevivência em períodos 49 desfavoráveis e em locais em que o fogo é um evento frequente. Além disso, como possuem 50 estatura menor, atingiriam a fase adulta mais rapidamente (Mimosa foliolosa floriu 1 ano e meio após o plantio em casa de vegetação) e produziriam sementes menores, que são facilmente enterradas, reduzindo a predação e exposição à altas temperaturas causadas pelo fogo, o que asseguraria o sucesso no ambiente savânico. As árvores, por outro lado, possuem como maior limitante ao recrutamento para o estágio adulto, a necessidade de escapar do fire-trap, evitando a mortalidade da parte aérea e alcançando o estágio reprodutivo. Desta forma, a redução da frequência de fogo nas savanas aumenta o recrutamento de árvores para o estágio adulto, favorecendo a formação de fisionomias florestais. As formações florestais reduzem a camada de gramíneas, e juntamente com ela a de subarbustos, que são competidores inferiores se comparadas às formas arbóreas. Portanto, para assegurar a manutenção da biodiversidade nos ecossistemas savânicos é necessário que políticas de manejo controlado de fogo sejam empregadas em todo o bioma, principalmente em unidades de conservação. 


\section{Introdução Geral}

A savana tropical brasileira, Cerrado, é caracterizada por um estrato rasteiro dominante, com presença de gramíneas, subarbustos e ervas, e um estrato arbóreo descontínuo, relativamente baixo (Gottsberger \& Silberbauer-Gottsberger 2006; Ratnam et al. 2011). O bioma Cerrado é a savana mais biodiversa do mundo, com mais de 12.000 espécies de angiospermas, 4.252 delas endêmicas (BFG 2015), e, diferentemente das outras savanas, não possui uma família dominante, sendo que poucas espécies (38 espécies) estão distribuídas em toda a extensão do bioma (Ratter et al. 2003). O bioma possui síndromes globais de regime de fogo (piromas), caracterizadas por eventos frequentes ( $1-4$ anos de intervalo de retorno de fogo), com o fogo podendo ter intensidade e altura de chama variável (ver Archibald et al. 2013). O regime de fogo pode ser definido como as características de intensidade ${ }^{1}$, frequência ${ }^{2}$, severidade ${ }^{3}$, sazonalidade, tamanho e extensão do fogo (Bond \& Keeley 2005), e englobar os processos mais antigos como as mudanças no clima e integrar também as influências humanas (Whitlock et al. 2010).

Os eventos de fogo provavelmente se tornaram mais frequentes no final do Mioceno, coincidindo com a expansão global das gramíneas $C_{4}$ (Pennington et al. 2006) e com a diversificação da flora do Cerrado (Simon et al. 2009). Desta forma, a flora do bioma evoluiu em um ambiente muito inflamável, levando à seleção de caracteres adaptativos ao regime de fogo. A maioria das espécies selecionadas a este ambiente possui casca espessa, órgãos de reserva e capacidade de rebrota (Hoffmann 2002; Gottsberger \& Silberbauer-Gottsberger 2006; Miranda et al. 2009). De forma geral, a dinâmica da vegetação do Cerrado é governada pelo regime de fogo, e não pela mortalidade (Hoffmann et al. 2009; Hoffmann et al. 2012a), sendo influenciada pelo clima regional e pelas características alométricas específicas das espécies lenhosas, de forma que a recuperação após a passagem de fogo depende das características de crescimento das mesmas (Lehmann et al. 2014).

Intervalos curtos entre queimadas (alta frequência) e alta intensidade de fogo geram vegetações mais abertas, com mais herbáceas, e um ambiente mais inflamável; e, inversamente, ambientes com baixa frequência de fogo permitem que os indivíduos da comunidade adquiram tamanho suficiente para resistir às chamas, de forma que o ambiente se torna mais fechado $e$ com menos biomassa combustível (Hoffmann et al. 2012a; Just et al. 2015). A menor quantidade de biomassa combustível, referente à baixa abundância de herbáceas, juntamente com a alta umidade e menor incidência de ventos garantem que as fisionomias florestais sejam menos susceptíveis às queimadas (Hoffmann et al. 2012b).

Nas matas de galeria, por exemplo, a maioria das espécies não teve uma história evolutiva influenciada pelo regime de fogo e, portanto, não desenvolveram caracteres de

\footnotetext{
${ }^{1} \mathrm{~A}$ intensidade de fogo se refere a energia liberada pelo fogo na sua passagem, e na prática, pode ser definida como a altura das chamas e a taxa de propagação. ${ }^{2} \mathrm{~A}$ frequência de fogo é a ocorrência de fogo em um determinado período de tempo em uma área. ${ }^{3} \mathrm{~A}$ severidade do fogo seria uma medida de impacto no ecossistema, como por exemplo a mortalidade de árvores em florestas ou o consumo de biomassa (Bond \& Keeley 2005; Keeley 2009).
} 
resistência e tolerância ao mesmo. Desta forma, é bem elucidado na literatura que, comparativamente às espécies de cerrado, as espécies de mata possuem uma menor razão raiz:parte aérea ( $82 \%$ menor), maior investimento em copa e menor investimento em casca e em reservas de raízes, o que se reverte em uma menor capacidade de rebrota e sobrevivência a eventos de fogo (Hoffmann 2000; Hoffmann et al. 2003; Hoffmann \& Solbrig 2003; Hoffmann et al. 2004; Hoffmann et al. 2005).

Dentro do próprio cerrado, as espécies podem responder de forma distinta ao regime de fogo. A literatura sugere que as formas de vida menores (subarbustos e ervas) seriam favorecidas em detrimento das formas de vida maiores (árvores) em áreas com alta frequência e intensidade de fogo (Gottsberger \& Silberbauer-Gottsberger 2006; Simon \& Pennington 2012). Isso ocorreria em decorrência de sincronismo de floração em relação ao fogo e uma melhor exploração dos nutrientes deixados pelo consumo da biomassa nas camadas superficiais do solo (cinzas), gerando transferência indireta de energia das espécies arbóreas e arbustivas para os subarbustos e gramíneas. Ademais, as formas de vida menores teriam maior capacidade de rebrota e menor perda de produtividade (flor e frutos) (Coutinho 1982; Gottsberger \& SilberbauerGottsberger 2006; Miranda et al. 2009). Além disso, para atingirem o estágio reprodutivo, as espécies arbóreas precisam de maiores intervalos sem fogo do que as subarbustivas e herbáceas (Hoffmann \& Solbrig 2003) e analogamente, as formas menores precisam de menos nutrientes para alcançarem o estágio adulto (Bond 2010).

Embora o debate sobre favorecimento de uma forma de vida em detrimento doutra em eventos de fogo exista, trabalhos com enfoque nas diferenças de caracteres adaptativos ao fogo são escasssos. Entender quais características da história de vida de uma espécie garantem sucesso em um ambiente é importante para inferir como os ecossistemas naturais serão afetados frente às perturbações antrópicas e mudanças climáticas. Desta forma, este trabalho tem como objetivo principal verificar as diferenças e semelhanças de caracteres adaptativos ao fogo em espécies arbóreas e subarbustivas do Cerrado. Para tanto, o trabalho será organizado em três capítulos: O primeiro com enfoque nas características fotossintéticas, alocação e uso de reservas, sobrevivência e capacidade de rebrota; o segundo com foco na capacidade reprodutiva entre as formas de vida, seleção de síndromes de polinização e dispersão; e o terceiro nas relações de competição interespecífica entre árvores e subarbustos e destes com a gramínea nativa do Cerrado Paspalum atratum.

\section{Referências:}

Archibald S., Lehmann C.E.R., Gómez-Dans J.L., Bradstock R.A. (2013). Defining pyromes and global syndromes of fire regimes. Proceedings of the National Academy of Sciences, 110, 6442-6447.

BFG (2015). Growing knowledge: an overview of seed plant diversity in Brazil. Rodriguésia, 66, 2-29.

Bond W.J. (2010). Do nutrient-poor soils inhibit development of forests? A nutrient stock analysis. Plant and Soil, 334, 47-60. 
Bond W.J., Keeley J.E. (2005). Fire as a global 'herbivore': the ecology and evolution of flammable ecosystems. Trends in Ecology \& Evolution, 20, 387-394.

Coutinho L.M. (1982). Ecological effects of fire in Brazilian Cerrado. In: Ecology of Tropical Savannas (eds. Huntley BJ, Walker BH). Springer Berlin, pp. 273-291.

Gottsberger G., Silberbauer-Gottsberger I. (2006). Life in the Cerrado, a South American Tropical Seasonal Ecosystem: origin, structure, dynamics and plant use. Reta Verlag, England.

Hoffmann W.A. (2000). Post-establishment seedling success in the Brazilian Cerrado: a comparison of savanna and forest species. Biotropica, 32, 62-69.

Hoffmann W.A. (2002). Direct and indirect effects of fire on radial growth of cerrado savanna trees. Journal of Tropical Ecology, 18, 137-142.

Hoffmann W.A., Adasme R., Haridasan M., Carvalho M.T., Geiger E.L., Pereira M.A.B., Gotsch S.G., Franco A.C. (2009). Tree topkill, not mortality, governs the dynamics of savanna-forest boundaries under frequent fire in Central Brazil. Ecology, 90, 1326-1337.

Hoffmann W.A., Geiger E.L., Gotsch S.G., Rossatto D.R., Silva L.C.R., Lau O.L., Haridasan M., Franco A.C. (2012a). Ecological thresholds at the savanna-forest boundary: how plant traits, resources and fire govern the distribution of tropical biomes. Ecology Letters, 15, 759-768.

Hoffmann W.A., Jaconis S.Y., McKinley K.L., Geiger E.L., Gotsch S.G., Franco A.C. (2012b). Fuels or microclimate? Understanding the drivers of fire feedbacks at savanna-forest boundaries. Austral Ecology, 37, 634-643.

Hoffmann W.A., Orthen B., Franco A.C. (2004). Constraints to seedling success of savanna and forest trees across the savanna-forest boundary. Oecologia, 140, 252-260.

Hoffmann W.A., Orthen B., Nascimento P.K.V. (2003). Comparative fire ecology of tropical savanna and forest trees. Functional Ecology, 17, 720-726.

Hoffmann W.A., Silva-Junior E.R., Machado G.C., Bucci S.J., Scholz F.G., Goldstein G., Meinzer F.C. (2005). Seasonal leaf dynamics across a tree density gradient in a Brazilian savanna. Oecologia, 145, 306-315.

Hoffmann W.A., Solbrig O.T. (2003). The role of topkill in the differential response of savanna woody species to fire. Forest Ecology and Management, 180, 273-286.

Just M.G., Hohmann M.G., Hoffmann W.A. (2015). Where fire stops: vegetation structure and microclimate influence fire spread along an ecotonal gradient. Plant Ecology, 1-14.

Keeley J.E. (2009). Fire intensity, fire severity and burn severity: a brief review and suggested usage. International Journal of Wildland Fire, 18, 116-126.

Lehmann C.E.R., Anderson T.M., Sankaran M., Higgins S.I., Archibald S., Hoffmann W.A., Hanan N.P., Williams R.J., Fensham R.J., Felfili J., Hutley L.B., Ratnam J., San Jose J., Montes R., Franklin D., Russell-Smith J., Ryan C.M., Durigan G., Hiernaux P., Haidar R., Bowman D.M.J.S., Bond W.J. (2014). Savanna vegetation-fire-climate relationships differ among continents. Science, 343, 548-552.

Miranda H.S., Sato M.N., Neto W.N., Aires F.S. (2009). Fires in the Cerrado, the Brazilian savanna. In: Tropical Fire Ecology (ed. Cochrane MA). Springer Berlin, pp. 427-450.

Pennington R.T., Richardson J.E., Lavin M. (2006). Insights into the historical construction of species-rich biomes from dated plant phylogenies, neutral ecological theory and phylogenetic community structure. New Phytologist, 172, 605-616.

Ratnam J., Bond W.J., Fensham R.J., Hoffmann W.A., Archibald S., Lehmann C.E.R., Anderson M.T., Higgins S.I., Sankaran M. (2011). When is a 'forest' a savanna, and why does it matter? Global Ecology and Biogeography, 20, 653-660.

Ratter J.A., Bridgewater S., Ribeiro J.F. (2003). Analysis of the floristic composition of the Brazilian Cerrado vegetation III: comparison of the woody vegetation of 376 areas. Edinburgh Journal of Botany, 60, 57-109.

Simon M.F., Grether R., Queiroz L.P., Skema C., Pennington R.T., Hughes C.E. (2009). Recent assembly of the Cerrado, a neotropical plant diversity hotspot, by in situ evolution of adaptations to fire. Proceedings of the National Academy of Sciences, 106, 20359-20364.

Simon M.F., Pennington T.R. (2012). Evidence for adaptation to fire regimes in the Tropical Savannas of the Brazilian Cerrado. International Journal of Plant Sciences, 173, 711-723.

Whitlock C., Higuera P.E., McWethy D.B., Briles C.E. (2010). Paleoecological perspectives on fire ecology: revisiting the fire-regime concept. The Open Ecology Journal, 3, 6-23. 


\title{
Small plants, great strategies: adaptations and survival of trees and subshrubs in a fire-prone ecosystem
}

\author{
Giroldo, A.B. ${ }^{1,2}$, Scariot, A. ${ }^{2}$, Hoffmann, W. A. ${ }^{3}$ \\ 1. Departamento de Ecologia, Universidade de Brasília, Caixa Postal 04457, 70919-970 Brasília, DF, \\ Brazil; Corresponding author: aeltonbg @gmail.com; 2. Embrapa Recursos Genéticos e Biotecnologia, Laboratório \\ de Ecologia e Conservação, Caixa Postal 02372, 70770-900 Brasília, DF, Brazil; 3. Department of Plant and \\ Microbial Biology, North Carolina State University, 2115 Gardner Hall, Box 7612, Raleigh, NC 27695, USA
}

\section{Abstract:}

Over the past 10 million years, tropical savanna environments have selected for small growth forms within woody plant lineages. The result has been the evolution of subshrubs (geoxyles) within many lineages of predominantly tree species, presumably as an adaptation to frequent fire. The main objective of this study was to evaluate the traits that favor subshrubs over trees in fire-prone ecosystems. We compared seed biomass, germination, survival, resprout capacity, biomass allocation, and photosynthesis between congeneric trees and subshrubs, and quantified the strength of phylogenetic conservatism. Despite the large differences in adult morphology between trees and subshrub species, as seedlings the differences are modest, and most of the variation in seedling traits was explained by phylogeny. Regardless, seedlings of tree species invested more heavily in aboveground growth, compared to subshrubs, which is consistent with the adult strategy of trees which depends on a large resistant-fire stem. Subshrub seedlings also invest in greater non-structural carbohydrate reserves, likely as an adaptation to the high fire frequencies typical of Neotropical savannas. These modest differences as seedlings suggest that selective pressures during early development may not have contributed substantially to the evolution of the subshrub growth form. Instead the distinct allocation and life history appear to arise later, and as adults, subshrubs differ from trees by reaching maturity at a small stem size, allowing them to reproduce despite repeated fire-induced topkill, but they produce smaller seeds than trees. The convergent evolution of subshrubs within multiple tree lineages reaffirms the importance of fire in the origin and diversification of the flora of mesic savannas. Furthermore, this assembled guild of subshrubs retains a strong phylogenetic signal of these diverse lineages, resulting in a Cerrado subshrub flora that is functionally quite diverse.

Key words: subshrub vs tree; Brazilian Savanna; savanna evolution; fire adaptations; traits phylogenetically conserved 
Introduction:

227 Evidence suggests that diversification of the tropical savanna woody flora began in the late Miocene, 228 following the expansion of C4 grasses and accompanying an increase in fire frequency (Simon et al. 2009, 229 Maurin et al. 2014). This flora was assembled from multiple lineages, many of which originated as trees 230 from evergreen or deciduous forests. Many of these lineages retained a tree growth form, but underwent natural selection for multiple traits, including thick bark, increased investment in belowground biomass and reserves, thick leaves, and reduced adult height. A more extreme example of this reduction in adult height is observed in subshrubs (geoxyles), which have diminutive aerial stems and large investment in belowground organs (see Gottsberger and Silberbauer-Gottsberger 2006, Simon and Pennington 2012). As adults, the belowground allocation of subshrubs is often so great these subshrubs are called underground trees (Warming 1908, White 1976, Simon and Pennington 2012, Bond 2016).

Trees and subshrubs represent starkly different outcomes of natural selection within the savanna environment. Although morphological differences between these growth forms are substantial as adults, it is not clear how these differences extend to physiological traits and seedling ecology, and consequently we lack a complete picture of the shift in life-history strategies that has accompanied the evolution of the subshrub habit. One possibility is that subshrubs represent an extreme endpoint in a continuum of woody plant adaptation to the savanna environment, with savanna trees being intermediate between forest trees and savanna subshrubs. Under this hypothesis, savanna subshrubs should exhibit more extreme values of a suite of traits shown to be typical of savanna trees, with seedlings exhibiting, for example, substantially lower values of specific leaf area (SLA), higher root-shoot ratio, and higher allocation to carbohydrate reserves, compared to trees of the same environment.

An alternative scenario is that savanna trees and subshrubs represent distinct life-history strategies that differ primarily during later development, as distinct strategies for ensuring reproduction under frequent burning. That is, adult savanna trees are able to maintain reproductive size in spite of fire because their large, fire-resistant stems are largely immune to fire (Hoffmann et al. 2009, Dantas and Pausas 2013). In contrast, the aerial biomass of subshrubs is totally consumed by fire, but they can resprout vigorously and reach reproductive size quickly after fire (Zizka et al. 2014). These differing strategies could be manifested largely as differences in size at maturity and investment in aboveground biomass of established plants, and might not involve differences in seedling traits or in leaf physiology. In fact, seedlings of trees and subshrubs are exposed to similar stresses and disturbances, and their stems should be equally vulnerable to fire, imposing similar needs for resprout capacity.

To better understand the suite of plant adaptations associated with the subshrub growth form, we compared congeneric trees and subshrubs of the Brazilian Cerrado to test for convergence in seedling and leaf traits in subshrubs across multiple lineages. Furthermore, we examined the strength of phylogenetic conservatism across lineages because of its potential to shape the functional diversity of subshrub communities. That is, if phylogeny has a strong influence on species traits, as is commonly documented 
(Verdú and Pausas 2007, Pausas and Verdú 2008, Souza-Neto et al. 2016), then the functional diversity of subshrubs should closely mirror the underlying diversity present in their ancestral tree species.

264 Considering that subshrubs arose independently from multiple and diverse lineages of tropical trees, trait conservatism should ensure high functional diversity across subshrubs species. Furthermore, this large diversity may obscure differences between trees and subshrubs, making it important to account for phylogenetic effects (see Hoffmann and Franco 2008).

\section{Materials and Methods:}

- Species selection and growth form classification

271 We selected 16 pairs of species, each containing one subshrub and one tree species from the same genus 272 and present in Brazilian Savanna. The use of these congeneric pairs allows us to confirm that similarities 273 found within the growth forms can be interpreted as convergent evolution, which is strong evidence of 274 natural selection, and not because of shared ancestral traits (Hoffmann and Franco 2008, de Bello et al. 275 2015). These genera represent 12 different families, which are well distributed across the angiosperm 276 phylogeny (Figure 1). We classified species as trees if they commonly possess a single, well-developed 277 and persistent stem of over $2 \mathrm{~m}$ tall. Subshrubs had an herbaceous-like morphology, with poorly developed stems, commonly without apical dominance and usually smaller than $1 \mathrm{~m}$.

\section{- $\quad$ Seed collection and sowing}

We were able to collect seeds of 11 of the species pairs. Most were collected in the vicinity of Brasilia, DF, Brazil, but seeds of Copaifera oblongifolia were collected in Chapada Gaúcha, MG, Anacardium humile was collected in Grão Mogol, MG and Mimosa foliolosa was collected in Serra da Canastra, São Roque de Minas, MG. We collected seeds between November, 2013 and July, 2014. We weighed 50 fresh seeds of each species using a precision scale $(0.0001 \mathrm{~g})$ to obtain mean seed mass. We sowed the species in polyethylene sacks containing approximately 12.5 I of soil (20 cm diameter x $40 \mathrm{~cm}$ deep), with three seeds per sack, and 60 sacks per species. Most were sown in February 2014, but Mimosa heringeri and M. speciosissima were sown in April, 2014 and the Stryphnodendron spp. were sown in July, 2014. Mimosa and Stryphnodendron seeds were immersed in sulfuric acid for 5 minutes to break physical dormancy. We used a substrate $70 \%$ oxisol subsoil (40 cm deep or more) mixed with $30 \%$ of washed sand, without added nutrients. The experiment was conducted in a greenhouse, with an automatic irrigation system supplying $7 \mathrm{~mm} /$ day. 


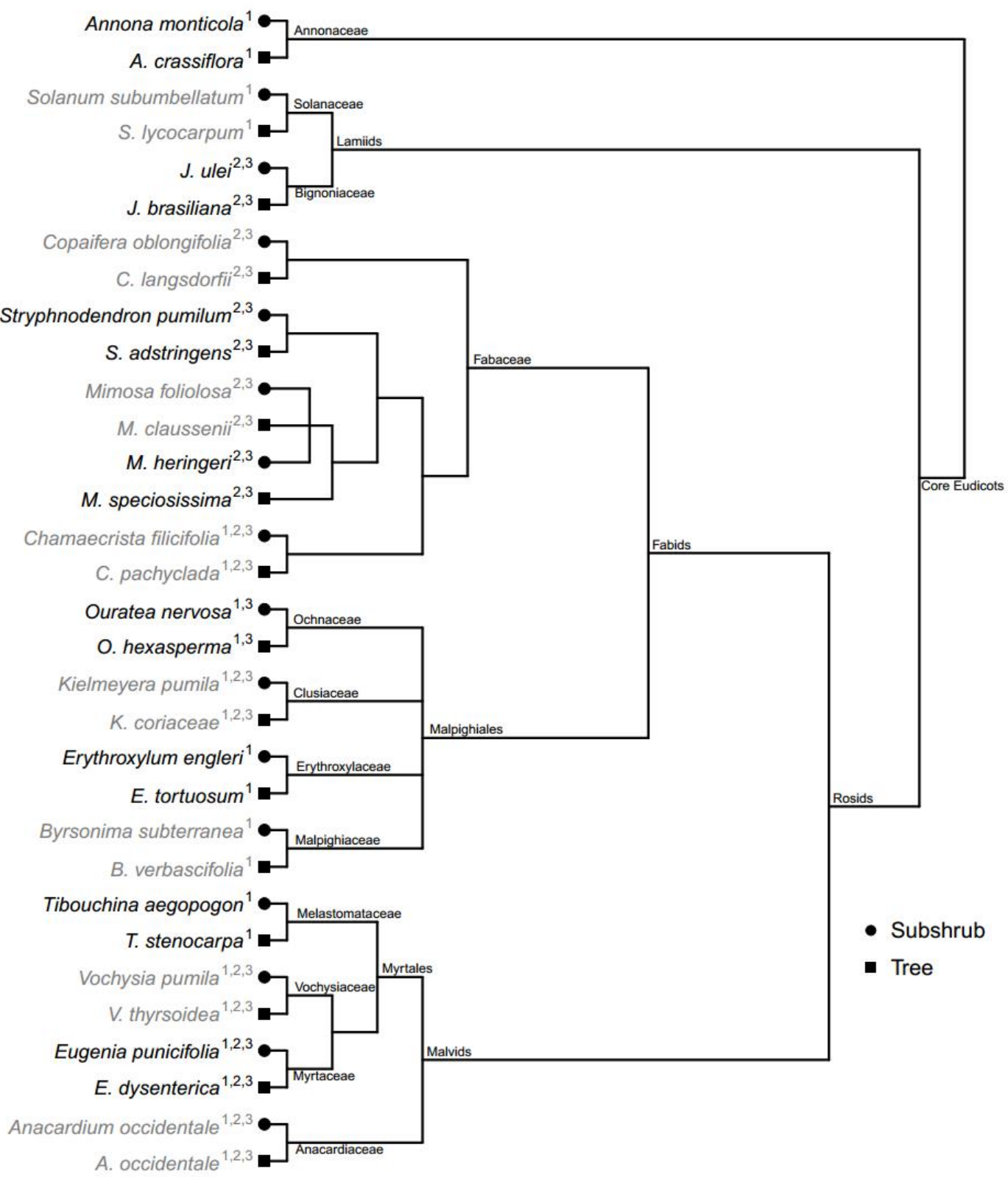

294 Figure 1. Phylogenetic tree for congeneric pairs of subshrubs and trees that occur in Brazilian Savanna. Phylogenetic relation was based on the current Phylomatic tree (tree R20120829 - Stevens (2001 onwards)). We improved the Mimosa clade using a more recent phylogeny (Simon et al. 2011). Alternating colors indicate congeneric pairs. Superscripts indicate data the data that were collected: ${ }^{1}$ photosynthesis, respiration, and SLA of adult plants were measured; ${ }^{2}$ germination and seedling traits were measured; ${ }^{3}$ seed mass was measured. 
300

301

302

303

304

305

306

307

308

309

310

311

312

313

314

315

316

317

318

319

320

321

322

323

324

325

326

327

328

329

330

331

332

We monitored germination and survival at monthly intervals. At 10 months after sowing, we randomly placed the plants into three groups. One group was kept as control, the second group was clipped at soil level to assess resprout capacity, and the third group was harvested to quantify biomass and reserves. For clipped plants, the number of individuals that resprouted in each sack was assessed monthly and resprout height was measured after six months. Harvested plants were washed in a sieve $(2 \mathrm{~mm})$ to remove all soil and were then divided into shoot and roots. Roots were submerged in liquid nitrogen to stop metabolic activity and were then lyophilized and stored with silica gel until analyzed for root carbohydrate reserves. Shoots were dried in a forced air chamber at $70^{\circ} \mathrm{C}$ for $72 \mathrm{~h}$, separated into leaves and stems (including petiole for species with compound leaves), and weighed on a precision scale $(0.0001 \mathrm{~g})$.

To analyze the root reserves we randomly selected six of the harvested individuals of each species, except Kielmeyera pumilum, for which only five individuals were selected. When there was more than one surviving individual per sack, we analyzed the largest. Samples were ground, and soluble sugar and starch were extracted and measured using the protocol of Amaral et al. (2007).

\section{- Photosynthesis, respiration and specific leaf area}

We located six adult individuals of each species in natural areas of Brasília, and using a portable photosynthesis system LCpro-SD (BioScientific Ltd.) we measured maximum photosynthesis rate and respiration on a leaf area basis. Measurements were performed on a fully expanded, healthy leaf, which was exposed to direct sunlight during part of the day. We performed measurements on one leaf per individual and recorded five measurements of photosynthesis per leaf at $1 \mathrm{~min}$ intervals after the exchange rate stabilized. Measurements were taken between 8:30 am and 12:30 pm with a photosynthetic photon flux density (PPFD) of $1,600 \mu \mathrm{mol} \mathrm{m} \mathrm{m}^{-2} \mathrm{~s}^{-1}$, chamber temperature at $30^{\circ} \mathrm{C}$ and open-flow mode $\left(\mathrm{CO}_{2}\right.$ concentration mean $\pm \mathrm{sd}$ was $\left.373 \pm 5 \mathrm{mmol} \mathrm{mol}^{-1}\right)$. We then measured the dark respiration of the same leaf by turning off the LED (PPFD $=0$ ) and covering the leaf chamber with aluminium foil. Specific leaf area (SLA) was measured in six individuals per species.

\section{- Statistical analysis}

We used mixed-effect models with interactions to verify differences between growth forms on ecophysiological traits: seed biomass, plant germination, survival, root reserves, photosynthesis rate, respiration rate, SLA, and resprout capacity. The models were built using growth form as a fixed factor, and genus as a random factor. The Gaussian distribution was used in most of the variables, exception was the resprout capacity that we used a Binomial distribution. When necessary, the response variable was log transformed to ensure the normality of residuals. To verify if traits were phylogenetically conserved we 
calculated the fraction of the total variance that was explained by growth form (fixed effect) and by genus (random effect) using the conditional $R_{G L M M}^{2}$, which describes the variance explained by fixed and random factors as a proportion of the sum of all the variance components (see Nakagawa and Schielzeth 2013, Johnson 2014).

While the previous analysis provides a test of phylogenetic signal across genera, we also tested for trait conservatism over the entire phylogeny using the Blomberg's $K$ and Pagel's $\lambda$ (Pagel 1999, Freckleton et al. 2002, Blomberg et al. 2003). Blomberg's $K$ is defined as the ratio between mean squared error (MSE) of the tip data divided by the MSE of data calculated using the variance-covariance matrix derived from the phylogenetic tree (see Blomberg et al. 2003 for details) and quantifies the degree of variation in a trait that can be explained by the phylogeny. If Blomberg's $K<1$, this indicates overdispersion, and traits have less phylogenetic signal than expected from Brownian motion (BM) model. If $K>1$, there is more phylogenetic signal than expected from BM model (Crisp and Cook 2012). The Pagel's $\lambda$ compares the distribution of a trait to that expected by BM. Low $\lambda$ values indicates little phylogenetic signal in a trait given, and high $\lambda$ values indicates a strong phylogenetic signal (Münkemüller et al. 2012, Swenson 2014).

To realize the Blomberg's $K$ and Pagel's $\lambda$ tests, we first constructed a phylogenetic tree with all 32 species. The current Phylomatic tree (R20120829) was used to estimate phylogenetic distances among taxa. The tree resolution was improved using data from Hedges and Kumar (2009). We dated the nodes using the "branch length adjustment" algorithm in Phylocom (Webb et al. 2008), and we obtained the age for major nodes in the tree from Hedges and Kumar (2009).

To verify the relationship between seed biomass and plant reserves or plant biomass in different growth forms we used Analysis of Covariance (ANCOVA), in this case the seed biomass was used as covariate, growth form as variable independent and plant reserves or plant biomass as dependent variable. The same approach was used to verify the relationship between SLA and photosynthesis or respiration rate, and in this case, SLA was included as a covariate. All analyses were conducted in $R$ program ( $R$ Development Core Team 2015), with the packages Ime4 (Bates et al. 2015), car (Fox and Weisberg 2011), brranching (Chamberlain 2016), phytools (Revell 2012), rncl (Michonneau et al. 2015), and ape (Paradis et al. 2004).

\section{Results:}

\section{- $\quad$ Seed and Plant Biomass}

On average, seeds of trees were $36 \%$ heavier than seeds of subshrubs $\left(F_{1,10}=6.015, p=0.034\right.$, Figure $2 \mathrm{~A})$. At an age of 10 months, total seedling biomass was $72 \%$ higher in trees than in subshrubs $\left(F_{1,9}=\right.$ 5.242, $p=0.048$, Figure $2 D)$. Similarly, trees had greater biomass of stems $\left(F_{1,9}=8.968, p=0.015\right)$, leaves $\left(F_{1,9}=8.921, \mathrm{p}=0.038\right)$, and shoots $\left(F_{1,9}=7.031, \mathrm{p}=0.026\right)$, but not of roots $\left(F_{1,9}=4.071, \mathrm{p}=\right.$ 
0.074). When compared in context of biomass allocation, the only significant difference between tree and subshrub was stem mass ratio $\left(F_{1,9}=32.788, P<0.001\right.$, Figure $\left.2 \mathrm{G}\right)$, which was $31 \%$ higher in trees than in subshrubs. Root mass ratio $\left(F_{1,9}=0.426, p=0.531\right)$, leaf mass ratio $\left(F_{1,9}=0.093, p=0.767\right)$ and root:shoot ratio $\left(F_{1,9}=0.476, \mathrm{p}=0.508\right)$ were not significantly different between growth forms. Seed biomass did not affect total plant biomass $\left(F_{1,16}=2.001, \mathrm{p}=0.176\right)$, and marginally affected the root biomass $\left(F_{1,16}=4.040, \mathrm{p}=0.062\right)$.

\section{- Germination and Survival}

Germination success did not differ significantly between subshrubs and trees $\left(F_{1,9}=3.171, \mathrm{p}=0.109\right)$; with means of $73 \pm 17 \%$ (mean $\pm s d$ ) and $62 \pm 27 \%$, respectively (Figure $2 B$ ). Survival after 10 months was similar between forms $\left(F_{1,9}=0.656, p=0.439\right)$, with survival of $81 \pm 18 \%$ for trees and $76 \pm 22 \%$ for subshrubs (Figure 2C). Resprout capacity did not consistently differ between life forms $\left(X^{2}=0.023, p=\right.$ 0.878 , Figure $2 \mathrm{~J}$ ), with mean resprouting of $57.5 \%$ for subshrubs and $53.0 \%$ for trees.

\section{- Carbohydrate reserves}

Root carbohydrate mass did not differ between the growth forms $\left(F_{1,9}=1.944, \mathrm{p}=0.197\right.$, Figure 2E), but nonstructural carbohydrate:structural biomass ratio of roots was $37 \%$ higher in subshrubs than trees $\left(F_{1,9}\right.$ $=5.830, p=0.039$, Figure $2 \mathrm{l})$. Root carbohydrate mass:total plant mass ratio was marginally significantly $\left(F_{1,9}=3.479, \mathrm{p}=0.095\right.$, Figure $\left.2 \mathrm{H}\right)$. There was a relationship between root carbohydrate mass and seed biomass $\left(F_{1,16}=13.457, \mathrm{p}=0.002\right)$, and root carbohydrate concentration was marginally correlated with seed biomass $\left(F_{1,16}=3.209, \mathrm{p}=0.092\right)$.

\section{- Photosynthesis, Respiration and Specific Leaf Area (SLA)}

There was no difference between growth forms in light-saturated photosynthesis $\left(F_{1,10}=0.053, p=0.823\right)$ dark respiration rate $\left(F_{1,10}=0.001, \mathrm{p}=0.968\right)$ or $\operatorname{SLA}\left(F_{1,10}=0.077, \mathrm{p}=0.787\right)$, and no correlation was detected between rates of photosynthesis $\left(F_{1,18}=0.519, \mathrm{p}=0.481\right)$ or respiration $\left(F_{1,18}=0.040, \mathrm{p}=0.843\right)$ with SLA.

\section{- Phylogenetic conservatism}

Overall, phylogeny explained much more of trait variation than did growth form. That is, genus explained more than $67 \%$ of the total variance in most traits. In contrast, the maximum variance explained by growth form was $6 \%$ for the traits total biomass and germination rate (Table 1). Even so, not all traits had a 
significant phylogenetic signal when the full phylogeny was considered. While seed mass, stem mass ratio, 400 root:shoot ratio and root carbohydrate biomass were phylogenetically conserved, the others 12 analyzed 401 traits were not (Table 1).

402 Table 1. Analyses of phylogenetic conservationism for ecophysiological traits in two differents growth forms 403 of Brazilian Savanna. The $R_{G L M M}^{2}$ was calculated using the Johnson (2014) and Nakagawa and Schielzeth 404 (2013) approach and represent total variance explained by genus and growth form in linear mixed models. 405 Variables with asterisks were log transformed. The $K$ represent the values in Blomberg's $K, \lambda$ the value of 406 Pagel's $\lambda$ test, $P_{1}$ and $P_{2}$ the p value in Blomberg's $K$ test and Pagel's $\lambda$, respectively.

\begin{tabular}{|c|c|c|c|c|c|c|}
\hline Trait & $R_{G L M M_{G e n u s}}^{2}$ & $R_{G L M M_{\text {Growth form }}}^{2}$ & $K$ & $\mathbf{p}_{1}$ & $\lambda$ & $\mathbf{p}_{2}$ \\
\hline Seed mass* & 0.94 & 0.02 & 0.97 & 0.004 & 1.01 & $<0.001$ \\
\hline Germination rate & 0.76 & 0.06 & 0.25 & 0.338 & $<0.01$ & $>0.999$ \\
\hline Survival rate & 0.76 & 0.01 & 0.51 & 0.047 & $<0.01$ & $>0.999$ \\
\hline Total plant mass* & 0.64 & 0.06 & 0.59 & 0.036 & 0.91 & 0.089 \\
\hline Root mass ratio & 0.69 & $<0.01$ & 0.64 & 0.012 & 0.84 & 0.101 \\
\hline Stem mass ratio & 0.68 & 0.05 & 0.79 & 0.003 & 0.97 & 0.012 \\
\hline Leaf mass ratio & 0.78 & $<0.01$ & 0.80 & 0.005 & 0.85 & 0.070 \\
\hline Root : Shoot ratio* & 0.70 & $<0.01$ & 0.74 & 0.010 & 0.96 & 0.020 \\
\hline Resprout rate* & 0.57 & $<0.01$ & 0.61 & 0.009 & 0.820 & 0.167 \\
\hline Photosynthesis rate & 0.42 & 0.02 & 0.16 & 0.543 & $<0.01$ & $>0.999$ \\
\hline Dark respiration rate & 0.42 & $<0.01$ & 0.34 & 0.263 & 0.37 & 0.370 \\
\hline Specific leaf area & 0.68 & $<0.01$ & 0.12 & 0.856 & $<0.01$ & $>0.999$ \\
\hline Nonstructural carbohydrate : structural biomass* & 0.68 & 0.04 & 0.68 & 0.080 & 0.72 & 0.202 \\
\hline Root carbohydrate mass* & 0.66 & 0.03 & 0.67 & 0.136 & 0.83 & 0.022 \\
\hline Root carbohydrate concentration ${ }^{\star}$ & 0.68 & 0.04 & 0.42 & 0.146 & 0.71 & 0.269 \\
\hline Root carbohydrate mass : Total plant mass* & 0.75 & 0.02 & 0.34 & 0.246 & 0.79 & 0.251 \\
\hline
\end{tabular}

408 Discussion:

409 Although the differences between trees and subshrubs are large and evident as adults (Poorter et al. 2012, 410 Díaz et al. 2016), we found surprisingly few consistent differences in seedling characteristics (Figure 2). 411 Instead, interspecific variation in seedling traits was consistently found to be most strongly determined by 412 genus (Table 1) than by growth form. Similar patterns were observed for leaf traits of adult plants.

413 Of all the seedling traits studied, investment in above-ground biomass and carbohydrate reserves 414 were the only ones to hint at the remarkable divergence between trees and subshrubs that develops later 415 in life. As seedlings, trees consistently invested a modestly larger fraction of their biomass in stems $(13 \%$ 416 versus $9 \%$, Figure $2 \mathrm{G}$ ) while subshrubs have greater investment in carbohydrate reserves (39\% versus 

accrue further as plants approach maturity, when subshrubs and trees exhibit starkly different strategies.
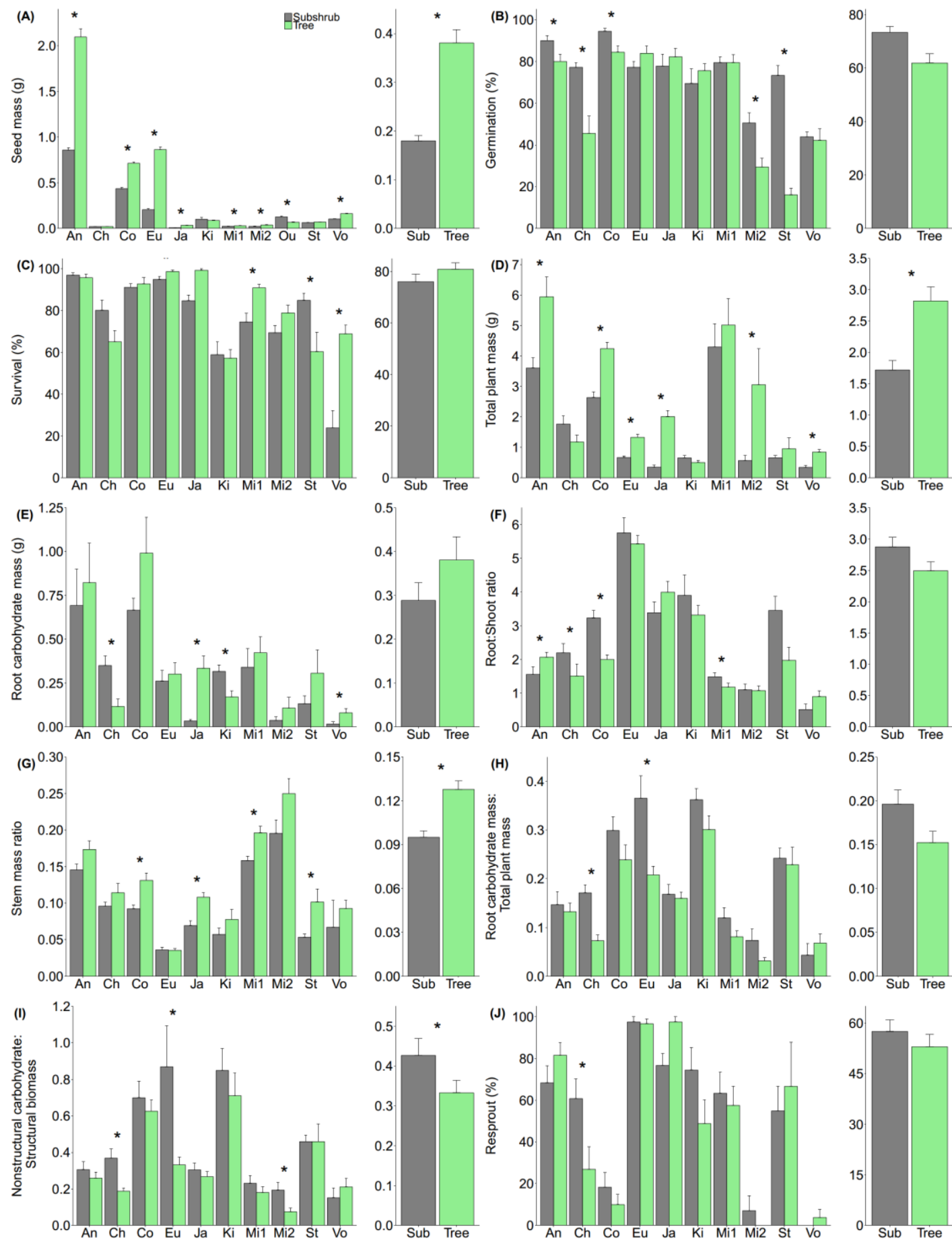

Figure 2. Seed and seedling traits (mean \pm SE) of congeneric pairs of subshrubs and trees in Brazilian Savanna. An asterisk indicates a significant difference $(p<0.05)$. The differences between congeneric pairs was calculated using $t$ test. $\mathrm{An}=$ Anacardium, $\mathrm{Ch}=$ Chamaecrista, $\mathrm{Co}=$ Copaifera, $\mathrm{Eu}=$ Eugenia, $\mathrm{Ja}=$ Jacaranda, $\mathrm{Ki}=$ Kielmeyera, Ou $=$ Ouratea, Mi1 and Mi2 $=$ Mimosa, St $=$ Stryphnodendron, $\mathrm{Vo}=$ Vochysia, $\mathrm{Sub}=$ Subshrub. 
Savanna trees exhibit an escape strategy (Zizka et al. 2014) that consist of early investment in height growth or early bark growth (Dantas and Pausas 2013), allowing them to become fire resistant. If stem growth is not sufficiently rapid, juvenile trees can be maintained indefinitely in a suppressed juvenile state due to repeated topkill by fire, thereby precluding sexual reproduction. Subshrubs, in contrast, are able to reproduce sexually despite repeated loss of aboveground biomass.

The modest differences in seedling allocation between savanna trees and subshrubs suggests that natural selection during establishment and early development has not been the primary factor driving the divergence of these growth forms. At this stage, seedlings of both growth forms are subject to an environment characterized by long dry seasons, low nutrient availability, and high risk of fire. In particular, fire is a particularly important factor in savannas, and may occur about once every 2-5 years (Gottsberger and Silberbauer-Gottsberger 2006, Archibald et al. 2013). The herbaceous aboveground layer is reduced by more than $90 \%$ after fire (Miranda et al. 2002), along with seedlings of trees and subshrubs, and must regrow from soil level. We found seedlings of both subshrubs and trees to recover similarly well following biomass loss, and exhibit similar functional traits. As plants develop, however, eventually a stem size is reached at which subshrubs are reproductively mature, while trees are neither mature nor large enough to resist fire (Figure 3). Is not clear whether both growth forms would maintain similar growth rates until this time, nor if they would exhibit similar allocation patterns. More importantly, however, is that this point marks the divergence between growth forms in their demographic responses to frequent fire. At this point, trees are susceptible to being maintained in a fire-trap of repeated topkill and resprouting, and may be maintained indefinitely in this suppressed state without an opportunity to reach reproductive maturity. Meanwhile subshrubs are generally able to recover reproductive size quickly between fires, thereby being able to produce seeds in the intervals between fire (Figure 3). So although allocation patterns may have diverged substantially prior to reaching this size, perhaps the most essential difference between these growth forms is the stem size at sexual maturity. However, this may have indirect effects on evolution of maximum size because evidence suggests a tradeoff between maximum size and ability to reproduce at small size (Aarssen 2015). Thus, the ability to reproduce while suppressed by frequent fires may preclude the ability to become a large, fire-resistant tree.

The ability to reproduce sexually at a small stem size allows successful reproduction despite frequent topkill, but imposes a cost upon the potential reproductive output. An adult tree may produce a vast number of seeds, while an adult subshrub has a much smaller amount of resources to invest in reproduction. Available resources can be invested in many small offspring or few large offspring (Henery and Westoby 2001, Muller-Landau et al. 2008, Díaz et al. 2016), and small growth forms tend to smaller seeds (Díaz et al. 2016). Selective pressure towards smaller offspring was detected as significantly smaller seeds and seedlings in subshrubs than in trees (Figure 2A). Yet, the number of offspring produced per unit plant size, per unit time describe the evolutionary fitness of a plant, and the most parsimonious way for a 
plant to make more seeds is to make smaller ones (Aarssen et al. 2006), and in ecosystems with limited time availability for plant growth, small reproductive plant size is favored (Aarssen 2015).

Other factors likely contributed to evolution of seed size in the Cerrado, but it is not clear whether they would consistently contribute to smaller seeds of subshrubs. Their smaller reserves results in smaller seedlings (Westoby et al. 2002) that would be more vulnerable to fire and drought, but such habitats with low seedling survival may favor production of many small seeds with high dispersal to enhance arrival at suitable sites (Smith and Fretwell 1974, Leishman et al. 2000, Moles and Westoby 2004). Furthermore, small seeds have been associated with lower capacity to withstand heat shock, such as that produced by fire (Ribeiro et al. 2015). However, tree recruitment in the Brazilian Savanna has been shown to be seed limited (Salazar et al. 2012) so predation in this environment has a substantial effect on seedling abundance by reducing the seed supply (Campbell and Clarke 2006, Salazar et al. 2012). Small seeds are easily buried, reducing predation and exposure to high temperatures in fire events, which would favor small seeds.

One remarkable feature of subshrub evolution is the fact that they arose independently within a large number of tropical tree lineages. These multiple origins suggest that the conquest of fire-prone ecosystems may require simple, easily acquired, genetic changes, perhaps involving gene regulation and rather than structural mutation (Simon and Pennington 2012). This could involve, for example, downregulation of gibberellin pathways, which is known to induce both dwarfism and flowering at smaller stem sizes (Davies 2010, Gupta and Chakrabarty 2013), two characteristics of subshrubs (Figure 3).

Regardless of the genetic mechanism, the evolutionary shift from tree to subshrub has relatively little impact on many species traits. In fact, for most traits, genus explained $>65 \%$ of the total interspecific variation across the study species, revealing strong phylogenetic conservatism of these traits. Each of these independent origins occurred within a lineage that possesses a unique suite of plant functional traits. This, combined with substantial conservatism of these traits at the genus level, has given rise to a functionally diverse community of subshrubs in the Cerrado, which largely mirrors the diversity of lineages from which the subshrubs evolved.

\section{Conclusions:}

These findings have multiple implications for the ecology and evolution of the subshrub (geoxyle) growth form, which is a diverse component of mesic savannas of South America and Africa. As seedlings, functional traits among our study species were more strongly determined by phylogeny than by growth form, but presumably this pattern is inverted later in development as plants differentiate into the highly distinctive tree and subshrub growth forms. Even so, leaf traits of adult plants continued to show little difference between growth forms, emphasizing the importance of the allocation and reproductive traits that characterize these growth forms. 


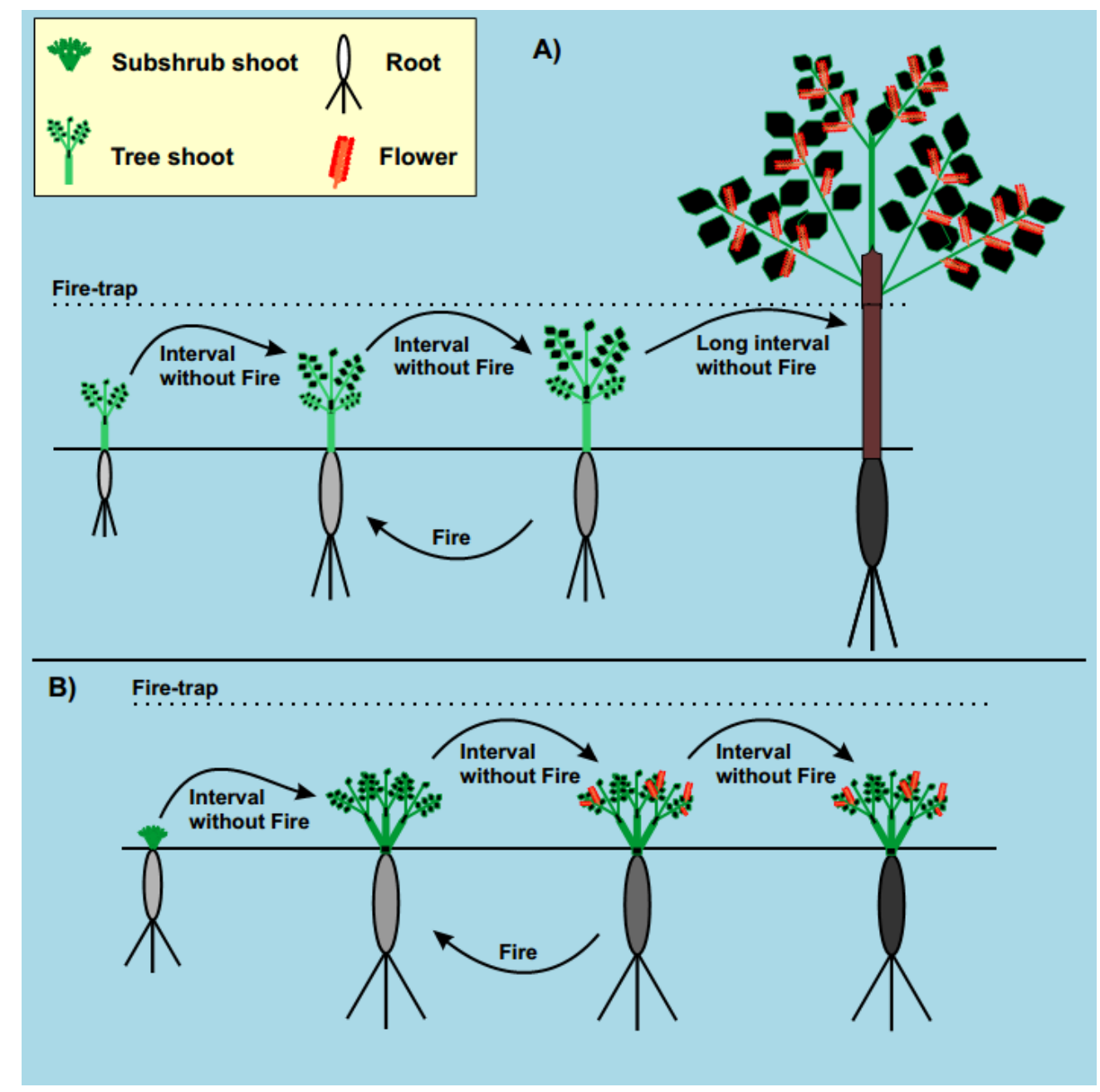

494 Figure 3. Schematic of the life histories of A) a tree and B) a subshrub, showing the differences in development and 495 reproduction and response to the frequent fire.

Nevertheless, there were several significant differences in several traits between subshrubs and trees across multiple independent lineages, revealing an influence of natural selection on these traits. Overall subshrubs had significantly smaller seeds, greater investment in carbohydrate reserves and less investment in aboveground growth during early development, all of which are consistent with a life history strategy involving adults that invest little in permanent aboveground structures and reproduce quickly after fire. On the other hand, trees are comparatively less adapted to habitats with high fire frequency. Although, they can remain "gullivers", this life-history strategy depends on longer free-fire intervals or alternatively many years of accumulating reserves for fueling sustained rapid growth to become fire resistant. These two different life-history strategies reaffirm the importance of fire events in the origin of savanna biodiversity

505 during the recent evolution and diversification of Brazilian savanna flora. Subshrubs comprise an important 506 component of this flora, which by means of extreme reduction in growth form have converged on an 507 effective strategy for the savanna environment. 


\section{References:}

Aarssen, L. W. 2015. Body size and fitness in plants: Revisiting the selection consequences of competition. Perspectives in Plant Ecology, Evolution and Systematics 17:236-242.

Aarssen, L. W., B. S. Schamp, and J. Pither. 2006. Why are there so many small plants? Implications for species coexistence. Journal of Ecology 94:569-580.

Amaral, L. I. V., M. Gaspar, P. M. F. Costa, M. P. M. Aidar, and M. S. Buckeridge. 2007. Novo método enzimático rápido e sensível de extração e dosagem de amido em materiais vegetais. Hoehnea 34:425-431.

Archibald, S., C. E. R. Lehmann, J. L. Gómez-Dans, and R. A. Bradstock. 2013. Defining pyromes and global syndromes of fire regimes. Proceedings of the National Academy of Sciences 110:6442-6447.

Bates, D., M. Maechler, B. Bolker, and S. Walker. 2015. Fitting linear mixed-effects models using Ime4. Journal of Statistical Software:1-51.

Blomberg, S. P., T. Garland, and A. R. Ives. 2003. Testing for phylogenetic signal in comparative data: behavioral traits are more labile. Evolution 57:717-745.

Bond, W. J. 2016. Ancient grasslands at risk. Science 351:120-122.

Campbell, M. L., and P. J. Clarke. 2006. Seed dynamics of resprouting shrubs in grassy woodlands: Seed rain, predators and seed loss constrain recruitment potential. Austral Ecology 31:1016-1026.

Chamberlain, S. 2016. brranching: Fetch 'Phylogenies' from Many Sources. R package version 0.2.0. http://CRAN.R-project.org/package=brranching.

Crisp, M. D., and L. G. Cook. 2012. Phylogenetic niche conservatism: what are the underlying evolutionary and ecological causes? New Phytologist 196:681-694.

Dantas, V. L., and J. G. Pausas. 2013. The lanky and the corky: fire-escape strategies in savanna woody species. Journal of Ecology 101:1265-1272.

Davies, P. J. 2010. Plant Hormones: Biosynthesis, signal transduction, Action! 3 edition. Springer, Dordrecht.

de Bello, F., M. P. Berg, A. T. C. Dias, J. A. F. Diniz-Filho, L. Götzenberger, J. Hortal, R. J. Ladle, and J. Lepš. 2015. On the need for phylogenetic 'corrections' in functional trait-based approaches. Folia Geobotanica 50:349-357.

Díaz, S., J. Kattge, J. H. C. Cornelissen, I. J. Wright, S. Lavorel, S. Dray, B. Reu, M. Kleyer, C. Wirth, I. Colin Prentice, E. Garnier, G. Bönisch, M. Westoby, H. Poorter, P. B. Reich, A. T. Moles, J. Dickie, A. N. Gillison, A. E. Zanne, J. Chave, S. Joseph Wright, S. N. Sheremet'ev, H. Jactel, C. Baraloto, B. Cerabolini, S. Pierce, B. Shipley, D. Kirkup, F. Casanoves, J. S. Joswig, A. Günther, V. Falczuk, N. Rüger, M. D. Mahecha, and L. D. Gorné. 2016. The global spectrum of plant form and function. Nature 529:167-171.

Fox, J., and S. Weisberg. 2011. An $\{$ R $\}$ Companion to Applied Regression. Second Edition edition. Sage, Thousand Oaks, CA. 
Freckleton, R., xa, P, P. Harvey, H, M. Pagel, and B. L. Associate Editor: Jonathan. 2002. Phylogenetic Analysis and Comparative Data: A Test and Review of Evidence. The American Naturalist 160:712726.

Gottsberger, G., and I. Silberbauer-Gottsberger. 2006. Life in the Cerrado, a South American Tropical Seasonal Ecosystem: origin, structure, dynamics and plant use. Reta Verlag, England.

Gupta, R., and S. K. Chakrabarty. 2013. Gibberellic acid in plant. Plant Signaling \& Behavior 8:e25504. Hedges, S. B., and S. Kumar. 2009. The Timetree of Life. Oxford University Press, New York.

Henery, M. L., and M. Westoby. 2001. Seed mass and seed nutrient content as predictors of seed output variation between species. Oikos 92:479-490.

Hoffmann, W. A., R. Adasme, M. Haridasan, M. T. Carvalho, E. L. Geiger, M. A. B. Pereira, S. G. Gotsch, and A. C. Franco. 2009. Tree topkill, not mortality, governs the dynamics of savanna-forest boundaries under frequent fire in Central Brazil. Ecology 90:1326-1337.

Hoffmann, W. A., and A. C. Franco. 2008. The importance of evolutionary history in studies of plant physiological ecology: examples from cerrados and forests of central Brazil. Brazilian Journal of Plant Physiology 20:247-256.

Johnson, P. C. D. 2014. Extension of Nakagawa \& Schielzeth's R2GLMM to random slopes models. Methods in Ecology and Evolution 5:944-946.

Leishman, M. R., I. J. Wright, A. T. Moles, and M. Westoby. 2000. The evolutionary ecology of seed size. Pages 31-57 in M. Fenner, editor. Seeds: the ecology of regeneration in plant communities. CABI Publishing, New York, NY.

Maurin, O., T. J. Davies, J. E. Burrows, B. H. Daru, K. Yessoufou, A. M. Muasya, M. van der Bank, and W. J. Bond. 2014. Savanna fire and the origins of the 'underground forests' of Africa. New Phytologist 204:201-214.

Michonneau, F., B. Bolker, M. Holder, P. Lewis, and B. O'Meara. 2015. rncl: an interface to the nexus class library. $R$ package version 0.6.0. http://CRAN.R-project.org/package=rncl.

Miranda, H. S., M. M. C. Bustamante, and A. C. Miranda. 2002. The fire factor. Pages 51-68 in P. S. Oliveira and R. J. Marquis, editors. The Cerrados of Brazil: ecology and natural history of a neotropical savanna. Columbia University Press, New York.

Moles, A. T., and M. Westoby. 2004. What do seedlings die from and what are the implications for evolution of seed size? Oikos 106:193-199.

Muller-Landau, H. C., S. J. Wright, O. Calderón, R. Condit, and S. P. Hubbell. 2008. Interspecific variation in primary seed dispersal in a tropical forest. Journal of Ecology 96:653-667.

Münkemüller, T., S. Lavergne, B. Bzeznik, S. Dray, T. Jombart, K. Schiffers, and W. Thuiller. 2012. How to measure and test phylogenetic signal. Methods in Ecology and Evolution 3:743-756.

Nakagawa, S., and H. Schielzeth. 2013. A general and simple method for obtaining R2 from generalized linear mixed-effects models. Methods in Ecology and Evolution 4:133-142.

Pagel, M. 1999. Inferring the historical patterns of biological evolution. Nature 401:877-884. 
Paradis, E., J. Claude, and K. Strimmer. 2004. APE: Analyses of Phylogenetics and Evolution in R language. Bioinformatics 20:289-290.

Pausas, J. G., and M. Verdú. 2008. Fire reduces morphospace occupation in plant communities. Ecology 89:2181-2186.

Poorter, H., K. J. Niklas, P. B. Reich, J. Oleksyn, P. Poot, and L. Mommer. 2012. Biomass allocation to leaves, stems and roots: meta-analyses of interspecific variation and environmental control. New Phytologist 193:30-50.

R Development Core Team. 2015. R: a language and environment for statistical computing. R Foundation for Statistical Computing, Vienna.

Revell, L. J. 2012. phytools: an R package for phylogenetic comparative biology (and other things). Methods in Ecology and Evolution 3:217-223.

Ribeiro, L. C., E. R. M. Barbosa, F. van Langevelde, and F. Borghetti. 2015. The importance of seed mass for the tolerance to heat shocks of savanna and forest tree species. Journal of Vegetation Science 26:1102-1111.

Salazar, A., G. Goldstein, A. Franco, and F. Miralles-Wilhelm. 2012. Seed limitation of woody plants in Neotropical savannas. Plant Ecology 213:273-287.

Simon, M. F., R. Grether, L. P. de Queiroz, T. E. Särkinen, V. F. Dutra, and C. E. Hughes. 2011. The evolutionary history of Mimosa (Leguminosae): toward a phylogeny of the sensitive plants. American Journal of Botany 98:1201-1221.

Simon, M. F., R. Grether, L. P. Queiroz, C. Skema, R. T. Pennington, and C. E. Hughes. 2009. Recent assembly of the Cerrado, a neotropical plant diversity hotspot, by in situ evolution of adaptations to fire. Proceedings of the National Academy of Sciences 106:20359-20364.

Simon, M. F., and T. R. Pennington. 2012. Evidence for adaptation to fire regimes in the Tropical Savannas of the Brazilian Cerrado. International Journal of Plant Sciences 173:711-723.

Smith, C. C., and S. D. Fretwell. 1974. The optimal balance between size and number of offspring. The American Naturalist 108:499-506.

Souza-Neto, A. C., M. V. Cianciaruso, and R. G. Collevatti. 2016. Habitat shifts shaping the diversity of a biodiversity hotspot through time: insights from the phylogenetic structure of Caesalpinioideae in the Brazilian Cerrado. Journal of Biogeography 43:340-350.

Stevens, P. F. 2001 onwards. Angiosperm Phylogeny Website. Version 12, July 2012 [and more or less continuously updated since].

Swenson, N. G. 2014. Comparative Methods and Phylogenetic Signal. Pages 147-171 in N. G. Swenson, editor. Functional and Phylogenetic Ecology in R. Springer New York, New York, NY.

Verdú, M., and J. G. Pausas. 2007. Fire drives phylogenetic clustering in Mediterranean Basin woody plant communities. Journal of Ecology 95:1316-1323.

Warming, E. 1908. Lagoa Santa: contribuição para a geographia phytobiologica. Imprensa Official do Estado de Minas Geraes, Belo Horizonte. 
618 Webb, C. O., D. D. Ackerly, and S. W. Kembel. 2008. Phylocom: software for the analysis of phylogenetic 619 community structure and trait evolution. Bioinformatics 24:2098-2100.

620 Westoby, M., D. S. Falster, A. T. Moles, P. A. Vesk, and I. J. Wright. 2002. Plant ecological strategies:

621 some leading dimensions of variation between species. Annual Review of Ecology and Systematics

$622 \quad 33: 125-159$.

623 White, F. 1976. The underground forests of Africa: a preliminary review. The Gardens' bulletin, Singapore $624 \quad 29: 57-71$.

625 Zizka, A., N. Govender, and S. I. Higgins. 2014. How to tell a shrub from a tree: a life-history perspective 626 from a South African savanna. Austral Ecology 39:1-12. 


\title{
Plant reproduction in a fire-prone ecosystem: traits selected
}

\author{
Giroldo, A.B. ${ }^{1}{ }^{2}$; Scariot, A. ${ }^{2}$; Massi, K.G. ${ }^{1}$; Walter, B.M.T. ${ }^{2}$; Hoffmann, W.A. ${ }^{3}$ \\ 1. Departamento de Ecologia, Universidade de Brasília, Caixa Postal 04457, 70919-970 Brasília, DF, Brazil. Corresponding author: \\ aeltonbg@gmail.com; 2. Embrapa Recursos Genéticos e Biotecnologia, Laboratório de Ecologia e Conservação, Caixa Postal \\ 02372, 70770-900 Brasília, DF, Brazil; 3. Department of Plant and Microbial Biology, North Carolina State University, 2115 Gardner \\ Hall, Box 7612, Raleigh, NC 27695, USA
}

\section{Abstract:}

How many species are able to reproduce after a fire event? Are some reproductive traits selected in fireprone ecosystems? These questions have intrigued researchers for a long time. We knew that savanna diversification occurred in the last 10 Mya and involved development of underground organs, thick terminal branches and bark, and resprout capacity. Small life forms represent, theoretically, the extreme of adaptation in fire-prone ecosystems, and most of them are able to reproduce after fire events. Using herbarium and literature data, we found that 2,058 species (16.6\%) in Cerrado biome are able to reproduce until one year after fire. The species represented $61 \%$ of the Cerrado families, and subshrubs represent $60 \%$ of the reproductive species after a fire, and trees $12 \%$. Although subshrubs are the dominant reproductive growth form in the Cerrado biome, surprisingly, the trees have higher chances of reproduction after a fire event. "The biased point of view" could explain why the naturalist thought, that the subshrubs reproduction, despite trees, are positively influenced by fire. We explained why trees reproduction are not negatively influenced by fire, using "fire as a pruning", and all traits correlated with tree survival in fire-prone ecosystems. We explored the importance of pollination and dispersion syndromes in plants that reproduce after fire. Reproduction of anemophilous species is not favored after fire events, however the number of pollinators is not negatively affected by fire, so there is not any reason to natural selection favor the windpollinated species after fire. Yet, we found an odds ratio in favor of zoochory species, and against autochory. The wind-dispersed species is not significantly favored in species able to reproduce after a fire, probably because there is a fast recovery of burnt areas, not favoring the long dispersion by wind.

Keywords: post-fire reproduction, pyrophytic species, Savanna evolution, Brazilian Savanna, Cerrado, pollination and dispersion syndromes.

\section{Introduction:}

“In October 8, 1864, a Cerrado grassland was burned... in October 25 the Cerrado's soil was covered with countless buds, and fresh and new flowers, I have never seen more beautiful grassland" (Warming 1908 page 90). The event related by Warming (1908) is a life history strategy of species in fire-prone ecosystems (Figure 1). Savanna diversification occurred in the Miocene, together with the spread of $\mathrm{C}_{4}$ grasses and 
enhancement of fire frequency (Simon et al. 2009). During the savanna diversification, species with thick bark, thick terminal branches, underground organs and resprout capacity were selected (Gottsberger \&

663 Silberbauer-Gottsberger 2006a; Simon \& Pennington 2012; Maurin et al. 2014), and some of them seem 664 to depend on fire for reproduction (Lamont \& Downes 2011; Rissi 2016).

665 Post-fire reproduction events are most reported for small growth forms, because, theoretically, herbs and 666 subshrubs are more adapted to fire-prone ecosystems than large growth forms (Simon \& Pennington 2012; 667 Maurin et al. 2014). The small growth forms invest proportionally large amount of energy in belowground 668 reserves (xylopodia) (Gottsberger \& Silberbauer-Gottsberger 2006a), have a lower investment in 669 aboveground growth and have an early investment in reproduction (Zizka et al. 2014). Apparently, the 670 induction of reproduction is not the result of thermal action or fertilization by ashes or gases emanating from 671 combustion, but from the effect of plant pruning at soil level (although, efficiently different, see Fidelis \& 672 Blanco (2014)) (Coutinho 1990). While herbaceous forms increase flower production after fire (Munhoz \& 673 Felfili 2005), woody forms usually decrease sexual reproduction (Coutinho 1982; Hoffmann 1998; García674 Nunez et al. 2001).

675 A high percentage of woody species are zoochorous, when compared with herbaceous species that are 676 mostly anemochorous and autochorous (Batalha \& Martins 2004; Ishara \& Maimoni-Rodella 2011). 677 Anemochorous species could be favored after a fire event because the biomass reduction in the ground678 layer allow seeds to disperse longer distances than when fire does not occur (Coutinho 1982, 1990). 679 Besides that, independently of the dispersal syndrome, the reduction of seed predators after fires can have 680 a positive effect on species fitness (Salazar et al. 2012) that are able to reproduce after fire. Understanding 681 species traits and growth forms that have high fitness in fire-prone ecosystems can highlight evidences of 682 the role of fire as an evolutionary force shaping plant adaptations (Bond \& Scott 2010; Keeley et al. 2011; 683 Pausas \& Schwilk 2012), and contribute to improve management in fire-prone ecosystems. In this context, 684 we quantified and identified all species able to reproduce in the Brazilian Savanna biome after fire events. 685 We asked: a) Which are the most able species to reproduce after the fire: savanna or forest species? b) 686 Are the small or large growth forms the most reproductive after a fire event? c) Is there any type of 687 pollination syndrome selected in species able to reproduce after a fire event? d) and dispersion syndrome? 688 We hypothesized that: a) most species that are able to reproduce after a fire event would be savanna 689 species, b) small growth forms, c) wind pollinated species and d) wind dispersed species. Yet, we tested if 690 there are some families with significant number of species reproducing after fire. The results are discussed 691 regarding savanna evolution and conservation. 

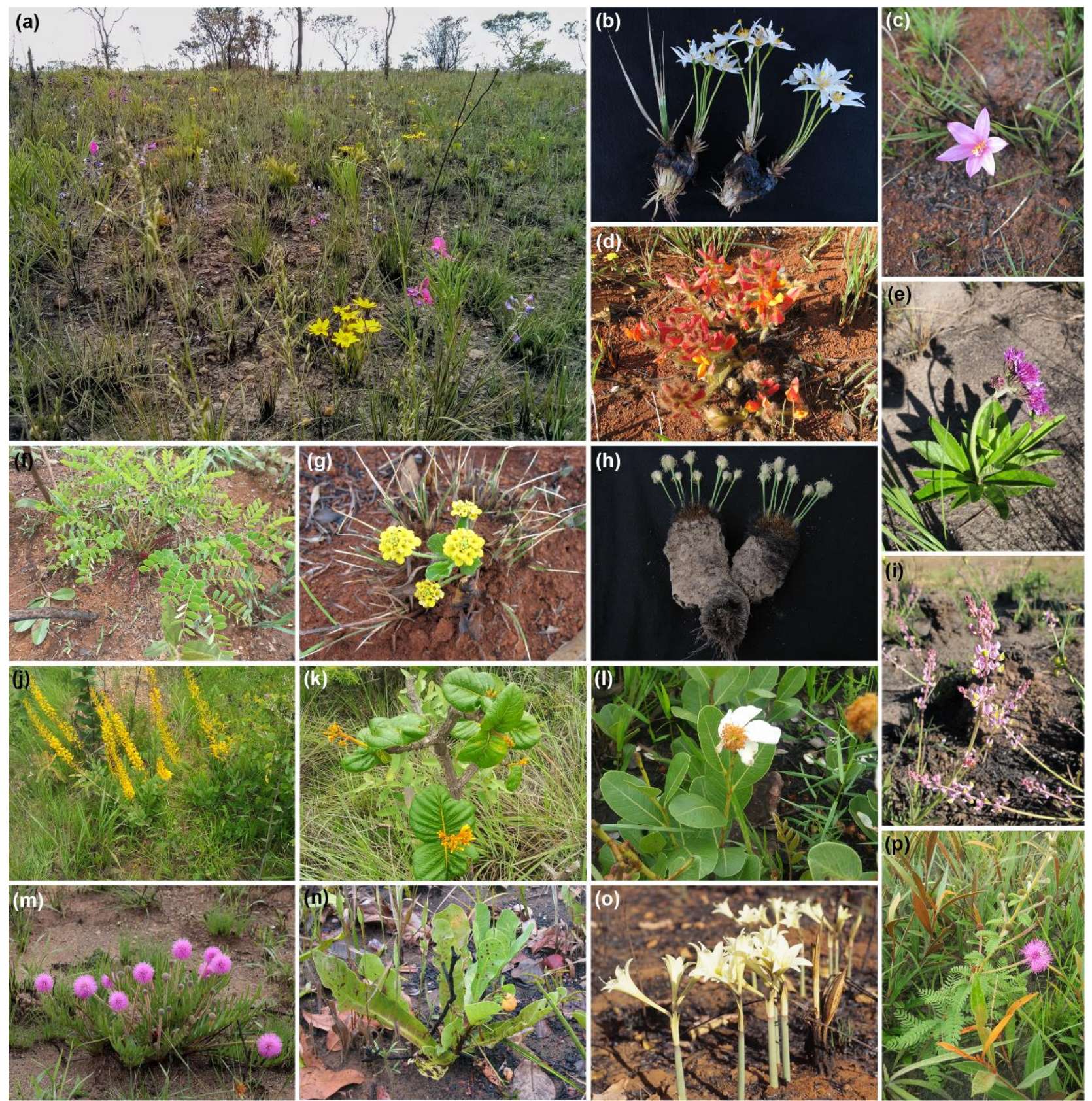

693 Figure 1. (a) A natural grassland in the Brazilian Savanna a few months after a fire event in Distrito Federal, Brazil; (b)

694 Vellozia sp. (Velloziaceae), (c) Habranthus irwinianus (Amaryllidaceae), (d) Eriosema prorepens (Fabaceae), (e)

695 Lessingianthus sp. (Asteraceae), (f) Stryphnodendron pumilum (Fabaceae), (g) Lippia pumila (Verbenaceae), (h)

696 Bulbostylis paradoxa (Cyperaceae), (i) Monnina sp. (Polygalaceae), (j) Vochysia pumila (Vochysiaceae), (k) Palicourea

697 rigida (Rubiaceae), (I) Kielmeyera pumila (Clusiaceae), (m) Mimosa speciosissima (Fabaceae), ( $\mathrm{n}$ ) Anacardium humile

698 (Anacardiaceae) with fruits, (o) Hippeastrum goianum (Amaryllidaceae), (p) Mimosa radula (Fabaceae). Photographs:

699 A.B. Giroldo (a,j-l,p), M.F. Simon (b-i,o), H. Moreira (m) and I.L.P. Lima (n). 
To define if a species is fire stimulated it is necessary to conduct experiments with and without fire. These type of studies were conducted in the Brazilian Savanna (see Araújo et al. 2013; Fidelis \& Blanco 2014), and produced valuable information about the effect of fire in flower production of some species. Using this approach it is possible to affirm if the species produce more flowers in areas with fire than without fire (firestimulated flowering species), if it does not produce flowers (fire-inhibited flowering species) or even if the production of flowers occurs just in areas with fire (a fire-dependent flowering species) (see Lamont \& Downes 2011). Although with our data was not possible to verify if a species is stimulated or dependent of fire to reproduce, we can affirm that the species is not inhibited and is able to reproduce after a fire event. We therefore considered here only species able to reproduce after fire.

\section{Data acquisition and classification:}

711 To create a list of species able to reproduce after a fire event (SAR) we checked two sources. We 712 accessed herbariums data using the speciesLink network (speciesLink 2015), and searched the English 713 words "fired", "fire", "burn" and "burned", the Portuguese words "queimada", "fogo", "incêndio", "queima",

714 "queimou", "queimado". We also searched for these words in the dataset from the large fire project 715 developed in the IBGE reserve, in Brasilia, Brazil (Miranda et al. 2011) for IBGE herbarium data is not 716 included at speciesLink network. We also verified if the species occurred in the Brazilian Savanna biome (Cerrado) checking each name in the Brazilian Flora Website (List of Species of the Brazilian Flora 2015)

718 and replaced synonyms by accepted names. We considered as species able to reproduce after fire,

719 species that were found with reproductive structure (fruits or flowers) until one year after the fire event.

720 The second source was the literature; we did an exhaustive search checking all available papers, seminars, short communications, and annals of events with data of species that reproduce after a fire event. We stopped searching when the effort to find plants was exacerbated compared with the results. As we collected the data from labels of herbarium specimens, we could not control the identification errors, common in herbariums, however the voucher number was kept in the list, and the identification can be checked in herbarium.

We verified the growth form of each species using the Brazil Flora website. As a species can be included in more than one growth form type (Warming 1908), we conducted analyses using growth forms as dummies, and classified them as subshrubs (herbs and subshrubs), shrubs, trees and vines. With information from labels of herbarium specimens and specialists knowledge (in special the specialist B.M.T. Walter) we classified species to either savanna/grassland or forest habitat. Savanna species were those with predominant occurrence in fire-prone formations of Brazilian Savanna biome, including savannic and grassland physiognomies. The forest species were those occurring mainly in forest physiognomies of the

733 Brazilian Savanna biome (see Ribeiro \& Walter 2008). We classified the pollination and dispersal 734 syndromes of each genus with information from scientific literature. We considered genus as an appropriate 735 proxy of the species when data was not available for a given species. Plant pollination syndromes were 
736

737

738

739

740

741

742

743

744

745

746

747

748

749

750

751

752

753

754

755

756

757

758

759

760

761

762

763

764

765

766

767

768

simplified into anemophily, entomophily and zoophily, and the dispersal syndromes into autochory, anemochory and zoochory.

\section{Data Analysis:}

We used basic statistics to describe the SAR patterns. To test if the families with higher number of species also had more species reproducing after a fire event we used a zero-inflated regression model with negative binomial distribution. Ignoring zero-inflation may generate an estimated parameter and standard error biased, and the excessive number of zeros can cause overdispersion (Zuur et al. 2009). Subsequently, we tested if the percentage of SAR by family was correlated with the number of species within the family using a generalized linear model (GLM), with binomial distribution (link logit), and calculated the $\mathrm{D}^{2}$ that is the equivalent of $R^{2}$ (coefficient of determination) for generalized linear models (GLMs) (Guisan \& Zimmermann 2000). To test the hypotheses: a) that plants in savanna are more likely to reproduce after fire than forest species; b) that the small growth forms are most able to reproduce after fire than large forms; c) that the wind pollination and d) wind dispersion syndromes are selected in species able to reproduce after a fire, we built a generalized linear model (GLM), using the binomial distribution with link logit. The independent variable in the model was transformed in dummies. This analysis allow us to include in the model species occurring in more than one habitat, growth form, pollination and dispersal syndrome, and test the main characteristics of species that reproduce after a fire in only one model. All epiphytic species were removed from this model. The analyses were done with $R$ program (R Development Core Team 2015), using the packages pscl (Jackman 2015), car (Fox \& Weisberg 2011) and modEva (Barbosa et al. 2016).

\section{Brazilian Savanna biome or Savanna physiognomies:}

The expression savanna is used to refer to physiognomies with trees and shrubs sparsed in a continuous grassy layer, without closed canopy (Ribeiro \& Walter 2008), and fire-prone. Yet, we included in this concept grassland formations (Ribeiro \& Walter 2008), so the expression savanna refers to fire-prone ecosystems (Figure 2). This expression differs from the expression Brazilian Savanna biome (named "Cerrado"), that includes forested physiognomies, like Cerradão, gallery forest, deciduous and semi-deciduous forests (Eiten 1972; Eiten 1978; Ribeiro \& Walter 2008). The forest physiognomies (hereafter Forest) have closer canopy if compared to savanna physiognomies, that suppresses the development of a grassy cover, mainly $\mathrm{C}_{4}$ grasses, the major determinant of fire spread/suppress along the savanna-forest gradient (Hoffmann et al. 2012b; Just et al. 2015). Fire in Central Brazil forests is a casual event, and fire adaptations are poorly developed in species there (Hoffmann et al. 2003), culminating in an environment tree/shrub species dominated (Figure 2). Savanna species have an odds to reproduce after a fire $1400 \%$ higher than forest species (Figure 3A), corroborating in part our first hypotheses, because forest species were not adversely affected by fire, and did not reduce the reproductive chances $(z=0.097, p=0.922)$ as we expected. 


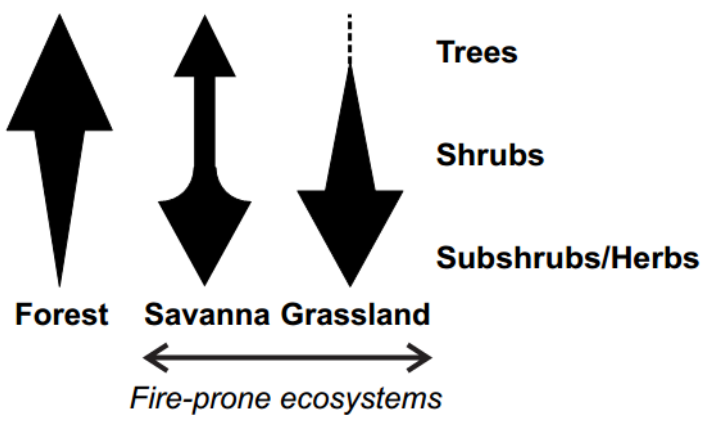

770 Figure 2. Differences in species number and abundance of growth forms in different vegetation formations within the 771 Brazilian savanna biome (Cerrado). The fire-prone ecosystems represent the savanna, where fire is one of the main

772 factors determining species abundance and richness.

773

774

775

776

777

778

779

780

781

782

783

784

785

786

787

788

789

790

791

792

793

794

795

796

797

\section{How many species can reproduce after a fire event?}

We found that 2,058 species are able to reproduce until one year after a fire event in Cerrado biome (Appendix 1), 1,942 species present in savanna, 455 in the Forest, and 342 common to both Forest and savana. The number of reproductive species after a fire is 5 times higher than the number of species reported in South Africa and Australia Savannas together (see Lamont \& Downes 2011), and represent more than $16 \%$ of the Cerrado Biome species. There are 181 families of Angiosperms in the Cerrado biome, and at least $61 \%$ of them are able to reproduce after a fire event. The families Fabaceae, Asteraceae, Poaceae and Orchidaceae had more than 100 species flowering after fire, and the ten families with the highest number of SAR comprise $56.6 \%$ of total reproductive species (Table 1). The total number of species reproducing after fire within a family is correlated with species richness within the family $(z=-2.321, p=$ 0.020) (Figure $4 A)$, and although the results for the percentage of SAR by family was significant $\left(X^{2}=\right.$ 22.997, $p<0.001$ ), the model had a poor adjust $\left(D^{2}=0.034\right)$, and do not represent correctly our data (Figure $4 \mathrm{~B})$. Yet, when considering the relative number of reproductive species and families with more than 10 species, it is possible to observe the families that are very well adapted to fire-prone ecosystems. Polygalaceae is an example (Table 1), with $46 \%$ of the species flowering after fire, and some of them just flowering after fire events (see Pastore \& Cavalcanti 2008); the diversification of the family happened near the tips and rather it is related to the roots of the tree (Forest et al. 2007), which could means recent diversification. Other prominent family is Vochysiaceae, with species very well distributed into Cerrado biome (see Ratter et al. 2003), and 34\% of them can reproduce after fire; this family is originated from South American and did not diversify until ca. 60 m.yr. (Sytsma et al. 2004, Forest and Chase 2009). Oxalidaceae and Malpighiaceae had about $32 \%$ of SARs. The high number of families able to reproduce after fire could push up the evolution process in favor of these families, once the sexual reproduction is linked directly with the process of adaptation and fitness enhancement (Barton \& Charlesworth 1998; Otto 2009), mainly in ecosystems like the Brazilian Savanna where the fire normally occurs once every five years (Gottsberger \& Silberbauer-Gottsberger 2006a). 


\section{Is reproduction between growth forms differentially influenced by fire?}

799 The small-sized growth forms are dominant in the group of species able to reproduce after fire, and almost $80060 \%$ of the SARs could be classified as subshrubs, and only $12 \%$ as trees in Cerrado biome (Figure 5A). 801 However, the dominance of small growth forms is similar to that showed in the Cerrado biome (Figure 5B), 802 and when we investigated savanna physiognomies, surprisingly, we found that $1 / 3$ of trees were able to 803 reproduce after a fire event, while just 1/4 of subshrubs had reproduced. In Forest, the differences were 804 higher, but not distinct, and less than $1 / 6$ of trees and only $1 / 16$ of subshrubs were able to reproduce until 805 one year after fire. The results of logistic regression with dummies point out same trend (Table 2), showing 806 that trees had an odd ratio higher than subshrubs, although both growth forms had high chances of 807 reproducing after a fire event (Figure 3B). These results mean that if an area has species equally distributed 808 in all life forms, the chances to find a tree reproducing after a fire is higher than to find a subshrub. This 809 statement did not corroborate the second hypothesis (b), that small life forms are most able to reproduce 810 than large growth forms after a fire event. We postulated some explanations about this result.

811 The first explanation could be called "the biased point of view", and could happen because when a naturalist 812 walks in a recently burnt field, the subshrubs are the most abundant growth form; they usually dominate 813 almost the whole landscape, covering all soil surface with vegetative parts and colorful flowers (Figure 1).

814 This pronounced cover could bias the naturalist view, who believes that subshrubs reproduction is positively 815 influenced by fire event, while the trees, that are sparse elements in the landscape, could be seen as 816 negatively influenced. The second explanation shows why trees reproduction was influenced by fire. If we 817 consider fire as an herbivorous (see Bond \& Keeley 2005), analogously we could consider it as a pruning 818 agent, despite the fact that fire could kill more plants than pruning (see Kelly et al. 1997). Pruning plants is 819 a common practice in agriculture and gardening, which enhances the productivity, by the production of new 820 leaves with high photosynthesis capacity, reduction of dead parts, and production of new branches. Yet, 821 although fire can destroy the buds and promote top-kill, the savanna trees which had escaped from the fire822 trap had thick terminal branches (Simon \& Pennington 2012) and thick bark that protect the buds and 823 cambium, allowing a vigorous epicornic resprout after the fire event (Hoffmann et al. 2009; Lawes et al. 824 2011; Pausas 2015); these characteristic could allow trees to recovery their vegetative part and reproduce 825 after a fire event. However, this does not mean that trees are stimulated to reproduce after a fire (as we 826 have mentioned in the second section); the fire regime intensification reduces the relative importance of sexual reproduction, and increases the importance of suckers in the vegetation and the most woody individuals are kept in a non-reproductive state (the "gullivers") (Hoffmann 1998; Bond \& Midgley 2001). 


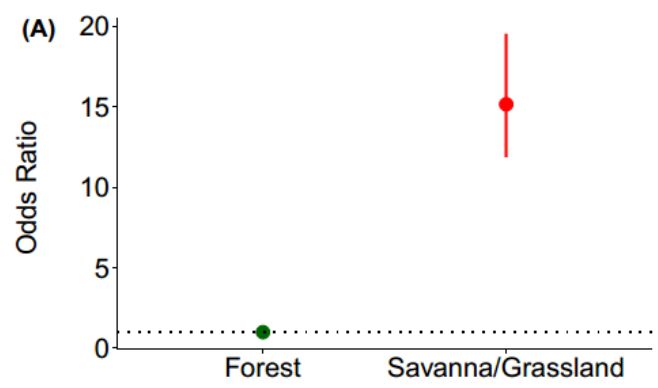

840 Table 1. $30^{\text {th }}$ families with most species able to 841 reproduce after a fire event in the Cerrado biome; 842 the relative number of species in relation to the 843 diversity of the family within the Cerrado (Relative 844 to Family); and in relation of all plants able to 845 reproduce after fire (Relative to SAR).
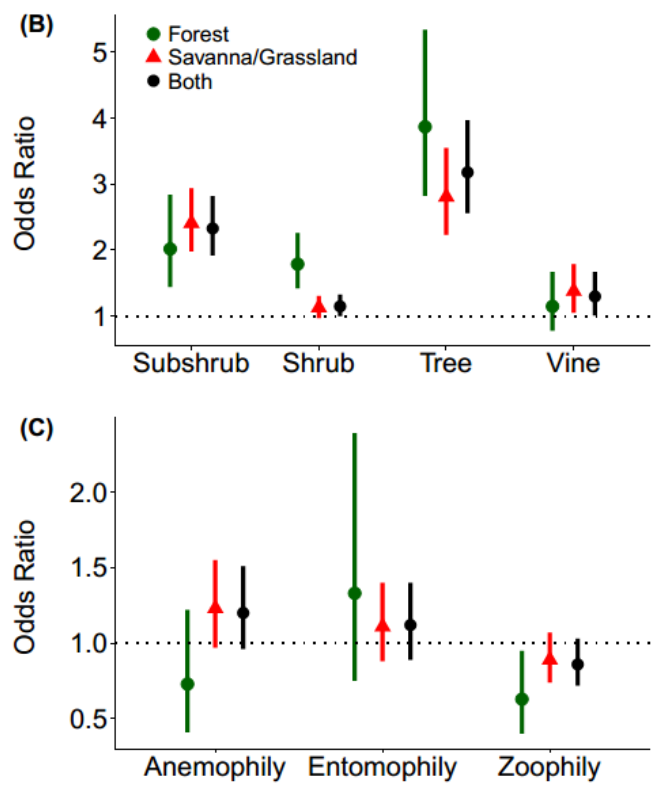

829

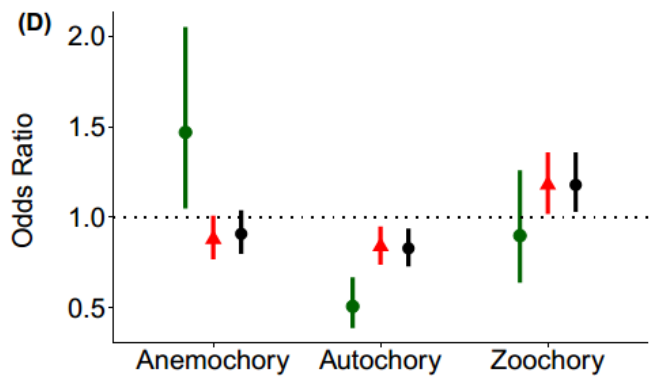

830 Figure 3. Odds ratio of species that reproduce after 831 fire in Forest and savanna (Savanna/Grassland) 832 (A), growth forms (B), pollination (C), and dispersal 833 syndromes (D) in the Cerrado biome. The dots 834 represent the mean and the arrows the confidence 835 interval (95\%).

\begin{tabular}{|c|c|c|c|}
\hline Families & \# Species & $\begin{array}{c}\text { Relative to } \\
\text { Family }\end{array}$ & $\begin{array}{c}\text { Relative to } \\
\text { SAR }\end{array}$ \\
\hline Fabaceae & 245 & 0.198 & 0.119 \\
\hline Asteraceae & 223 & 0.180 & 0.108 \\
\hline Poaceae & 153 & 0.206 & 0.074 \\
\hline Orchidaceae & 129 & 0.177 & 0.063 \\
\hline Euphorbiaceae & 87 & 0.224 & 0.042 \\
\hline Malpighiaceae & 74 & 0.318 & 0.036 \\
\hline Myrtaceae & 68 & 0.260 & 0.033 \\
\hline Lamiaceae & 63 & 0.211 & 0.031 \\
\hline Melastomataceae & 62 & 0.127 & 0.030 \\
\hline Cyperaceae & 61 & 0.184 & 0.030 \\
\hline Rubiaceae & 57 & 0.137 & 0.028 \\
\hline Apocynaceae & 56 & 0.189 & 0.027 \\
\hline Polygalaceae & 52 & 0.473 & 0.025 \\
\hline Eriocaulaceae & 40 & 0.087 & 0.019 \\
\hline Malvaceae & 37 & 0.110 & 0.018 \\
\hline Convolvulaceae & 35 & 0.136 & 0.017 \\
\hline Bignoniaceae & 31 & 0.183 & 0.015 \\
\hline Lythraceae & 28 & 0.170 & 0.014 \\
\hline Bromeliaceae & 26 & 0.098 & 0.013 \\
\hline Amaranthaceae & 25 & 0.219 & 0.012 \\
\hline Acanthaceae & 24 & 0.159 & 0.012 \\
\hline Turneraceae & 23 & 0.247 & 0.011 \\
\hline Velloziaceae & 23 & 0.122 & 0.011 \\
\hline Verbenaceae & 23 & 0.154 & 0.011 \\
\hline Solanaceae & 22 & 0.204 & 0.011 \\
\hline Arecaceae & 16 & 0.170 & 0.008 \\
\hline Vochysiaceae & 16 & 0.340 & 0.008 \\
\hline Iridaceae & 15 & 0.221 & 0.007 \\
\hline Oxalidaceae & 15 & 0.326 & 0.007 \\
\hline Ochnaceae & 13 & 0.176 & 0.006 \\
\hline
\end{tabular}




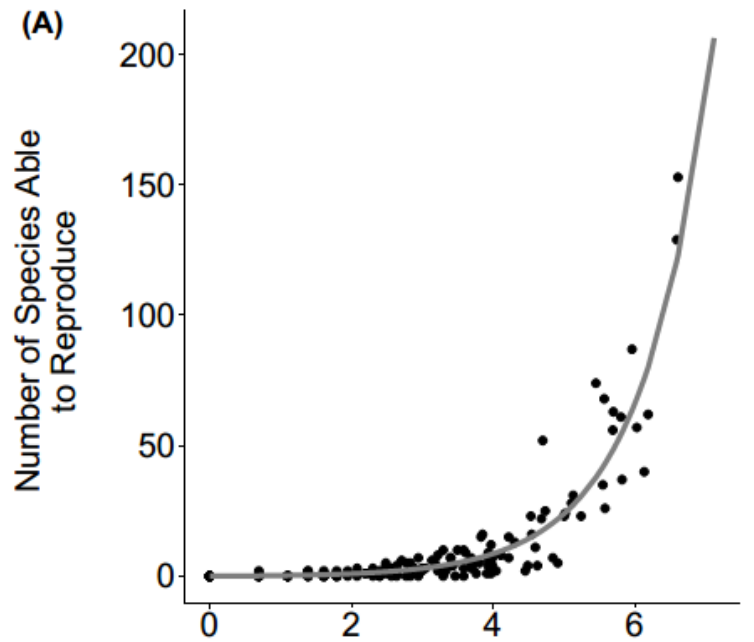

Log Number of Species per family

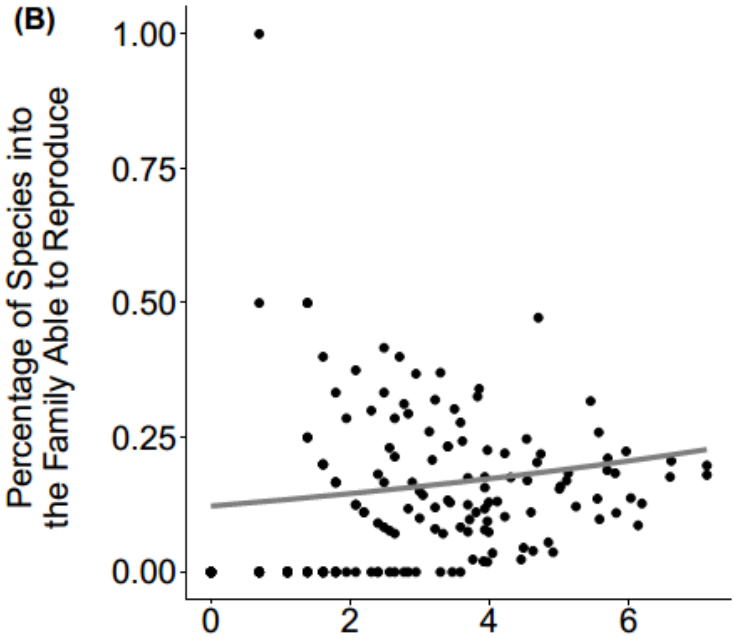

Log Number of Species per family

Figure 4. Number of species able to reproduce after fire in Cerrado biome (A), and percentage of species

849 within the family able to reproduce per number of species per family (B). The dots represent observed data

850 and the lines the predict zero-inflated model (A), and logistic model (B).

851 Table 2. Result from the logistic regression model, with species able to reproduce after fire as a dependent 852 variable, and independent variable the physiognomies in Cerrado biome, Forest and savanna/ grassland

853 (savanna); growth forms, subshrub, shrub, tree and vine; pollination syndromes, anemophily, entomophily 854 and zoophily; and dispersal syndromes, anemochory, autochory and zoochory of plants in Cerrado biome.

\begin{tabular}{lcrr}
\hline Independent Variable & Estimate $\pm \mathbf{S E}$ & $\mathbf{z}$ value & \multicolumn{1}{c}{$\mathbf{p}$} \\
\hline Forest & $0.008 \pm 0.078$ & 0.097 & 0.922 \\
Savanna/grassland & $2.719 \pm 0.127$ & 21.366 & $<0.001$ \\
Subshrub & $0.844 \pm 0.097$ & 8.693 & $<0.001$ \\
Shrub & $0.142 \pm 0.073$ & 1.942 & 0.052 \\
Tree & $1.158 \pm 0.112$ & 10.377 & $<0.001$ \\
Vine & $0.262 \pm 0.129$ & 2.038 & 0.041 \\
Anemophily & $0.183 \pm 0.116$ & 1.579 & 0.114 \\
Entomophily & $0.110 \pm 0.114$ & 0.965 & 0.334 \\
Zoophily & $-0.148 \pm 0.927$ & -1.602 & 0.109 \\
Anemochory & $-0.089 \pm 0.068$ & -1.312 & 0.189 \\
Autochory & $-0.184 \pm 0.064$ & -2.891 & 0.004 \\
Zoochory & $0.169 \pm 0.070$ & 2.401 & 0.016 \\
\hline
\end{tabular}



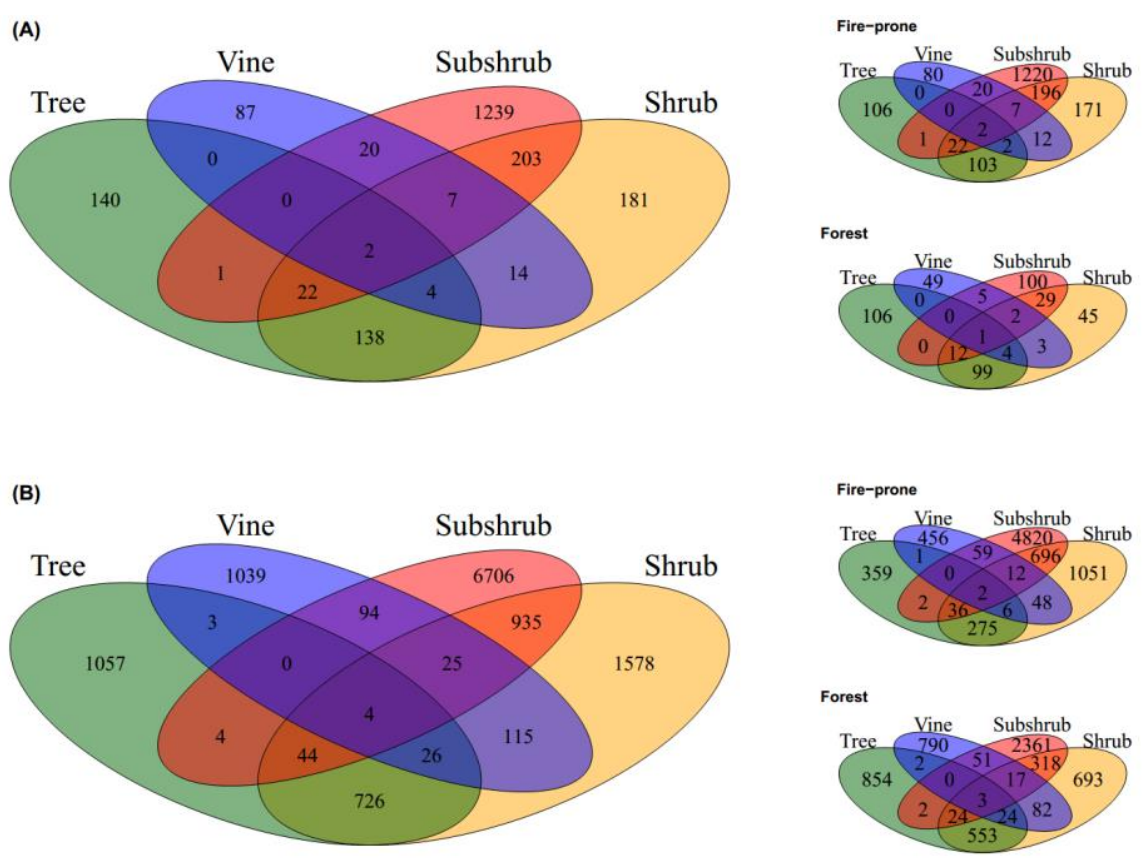

Figure 5. Number of species able to reproduce after a fire in each growth form (A); and in Cerrado biome (B), divided by fire-prone habitats (savanna) and Forest.

\section{Pollination syndromes related with fire}

859 The dominance of animal pollinated species (zoophily and entomophily species) and the 860 reduction of the anemophily syndrome found here (Figure $6 \mathrm{~A}$ ) may reflect the rainforest origin of 861 the Brazilian Savanna (Oliveira \& Gibbs 2002). Although some families have different pollination 862 syndromes in the Forest and savanna physiognomies, generally the pollination traits are 863 conservative (see Gottsberger 1986) (Figure 6A); and many plants in the "Cerrado" have 864 polyphilic flowers, which are pollinated by taxa of totally unrelated groups (egg. by different bees 865 and flies or beetles), so the pollinators may be substituted depending upon the fauna composition 866 at a particular place (Gottsberger \& Silberbauer-Gottsberger 2006b). Yet, there were not 867 differences in the odds ratio of pollination syndrome in species able to reproduce after a fire (Table 8682 - Figure $3 \mathrm{C}$ and $6 \mathrm{~B}$ ), meaning that no syndrome is benefited in the availability of plants flowering 869 after fire events. Even when we built the model using just savanna (Savanna/Grassland) species 870 no syndrome appears with high or low odds ratio (Figure $3 \mathrm{C}$ ), although the anemophily syndrome 871 was marginally significant $(z=1.706, p=0.088)$. Moreover, using just Forest species, the zoophily 872 syndrome had an odds $37 \%$ smaller to reproduce than by chance $(z=-2.099, p=0.036)$. These 873 results did not corroborate the hypothesis (c), that the wind-pollinated species were selected in 874 species able to reproduce after fire. However, investigating the data by growth forms we found 875 that anemophilous species had an odd ratio significantly higher than the chance in vines $876(z=2.246, p=0.025)$ and shrubs $(z=3.811, p<0.001)$, and the odd ratio of entomophilous $(z=-$ $8770.079, p=0.038)$ and zoophilous trees $(z=-2.422, p=0.015)$ was smaller than by chance (Figure 878 7A). The evolution process could really favor the wind-pollinated plants if the fire negatively 879 affected the pollination guilds. However, the main effect of fire in pollination is the enhancement 
of it, because usually the number of plants that produce new flowers, mainly in herbaceous stratum, increases (see Campbell et al. 2007; Van Nuland et al. 2013), and the rewards for pollinators (pollen and nectar) are smaller in mature areas than in freshly burnt areas (Potts et al. 2003). However, probably this pattern is kept mainly because Cerrado species have polyphilic flowers, and can be pollinated by multiple pollinators. Species that depends on solitary bees could be negatively affected, since these type of pollinator is more specialist, and usually decrease in abundance in recently burnt areas (see Ne'eman et al. 2000). The effects on species dependence of specialist pollinators need to be investigated, as well as the effect of fire in all guilds of pollinator, mainly in neotropical savanna, where fire frequency and species diversity are high.

889
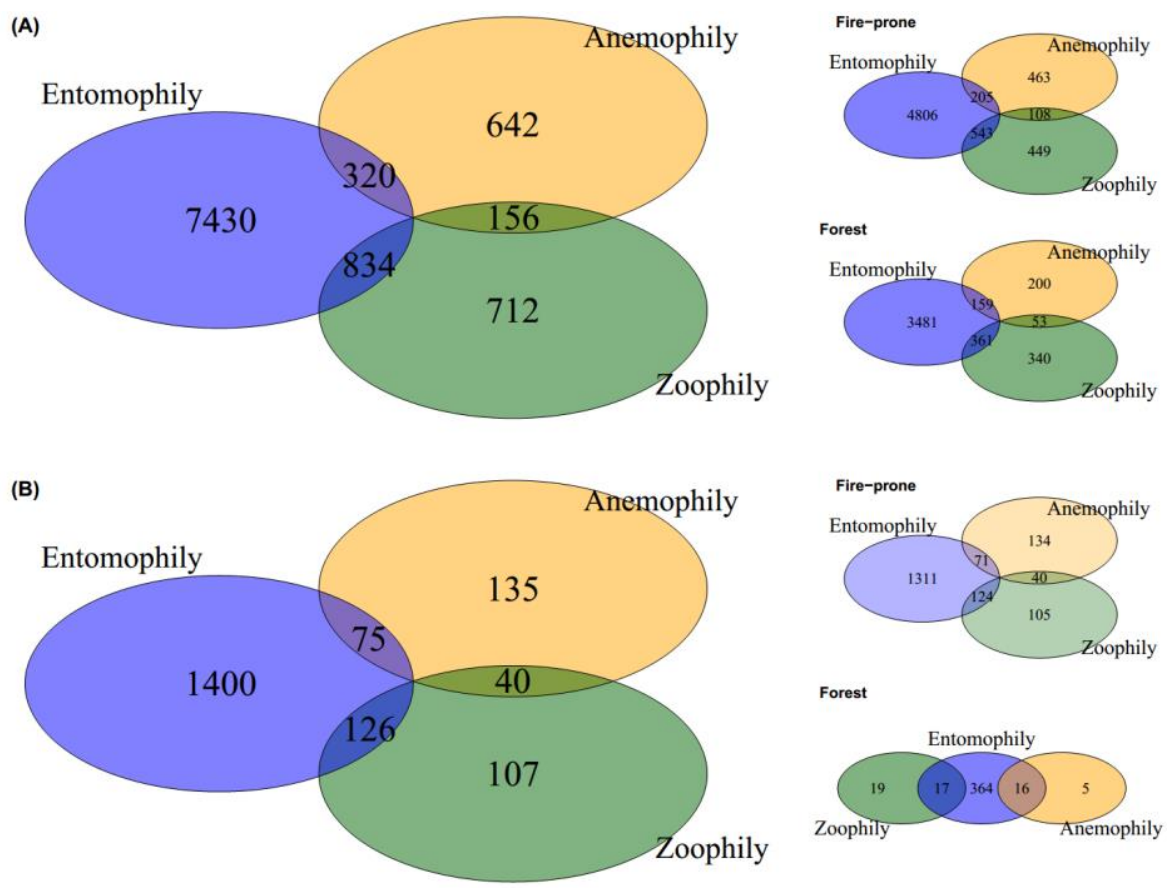

Figure 6. Number of species in each pollination syndrome in Cerrado biome (A); able to reproduce into pollination syndromes (B), all of them separated by savanna (fire-prone) and Forest physiognomies. 

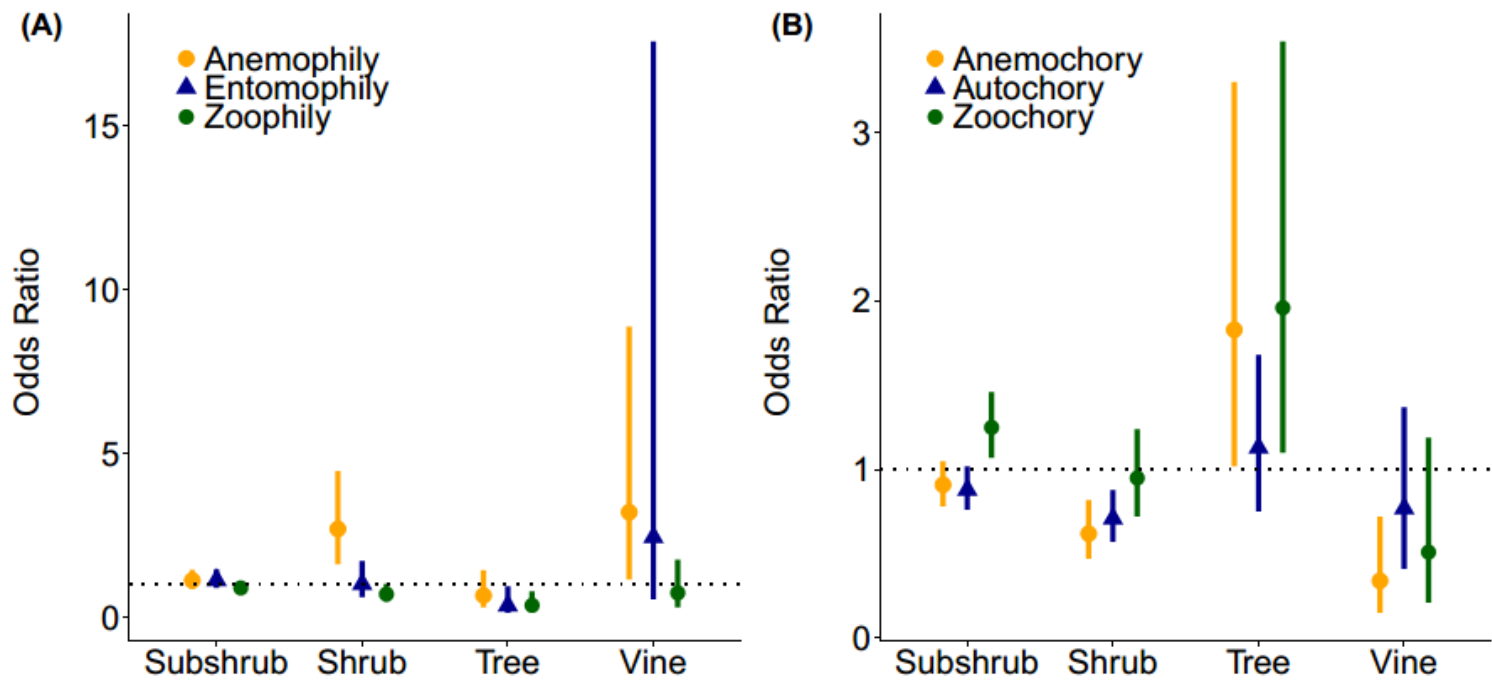

Figure 7. Odds ratio of species able to reproduce after fire in pollination syndromes $(A)$ and dispersal syndromes $(B)$ of different growth forms in Cerrado biome.

\section{Dispersal syndromes related with fire:}

The environmental gradient affect the dispersal syndromes. At landscape level the wind dispersion is related with nutrient and light availability, wherein the increased nutrient results in the reduction of species wind dispersed, and increased light increases anemochorous species. The zoochorous species have complex relations; while mammals dispersed species increase with light availability, bird dispersed species decrease with light availability (Ozinga et al. 2004). As a result of these relationships, and given the vegetation structure differences between Forest and Brazilian savana physiognomies (see Ribeiro \& Walter 2008), the dispersal syndromes are not conserved between them. Instead, Forest physiognomies are dominated by zoochorous species, while savanna physiognomies are dominated by anemochorous species (Figure 8A) (further examples Gottsberger \& Silberbauer-Gottsberger 2006b; Jacobi \& Carmo 2011). However, when referring to species able to reproduce after fire in Cerrado biome, zoochorous species had an odds ratio higher than by chance, and autochorous species had a reduction in the odds ratio (Table $2-$ Figure 3D and 8B). These results are kept even in savanna (Autochory: $z=-2.712, p$ $=0.007$; Zoochory: $z=2.257, p=0.024)$, but not in Forest, where the anemochorous species had an odd ratio higher than by chance $(z=2.262, p=0.024)$, autochorous lower than by chance ( $z$ $=-4.820, p<0.001)$ and zoochorous were not significantly affected $(z=-0.628, p=0.530)$. We did not find any pattern of dispersal syndromes with growth form; each growth form had a predominant type of dispersion in SARs. Subshrubs showed high odds chance for zoochorous species $(z=2.865, p=0.004)$; shrubs had low odds ratio for anemochorous $(z=-3.396, p=$ $0.001)$ and autochorous $(z=-3.108, p=0.002)$; trees had high odds ratio in anemochorous $(z=$ 2.030, $p=0.042)$ and zoochorous species $(z=2.252, p=0.024)$; and vine had lower odds ratio than by chance for anemochorous species $(z=-2.745, p=0.006-$ Figure $7 \mathrm{~B})$. 

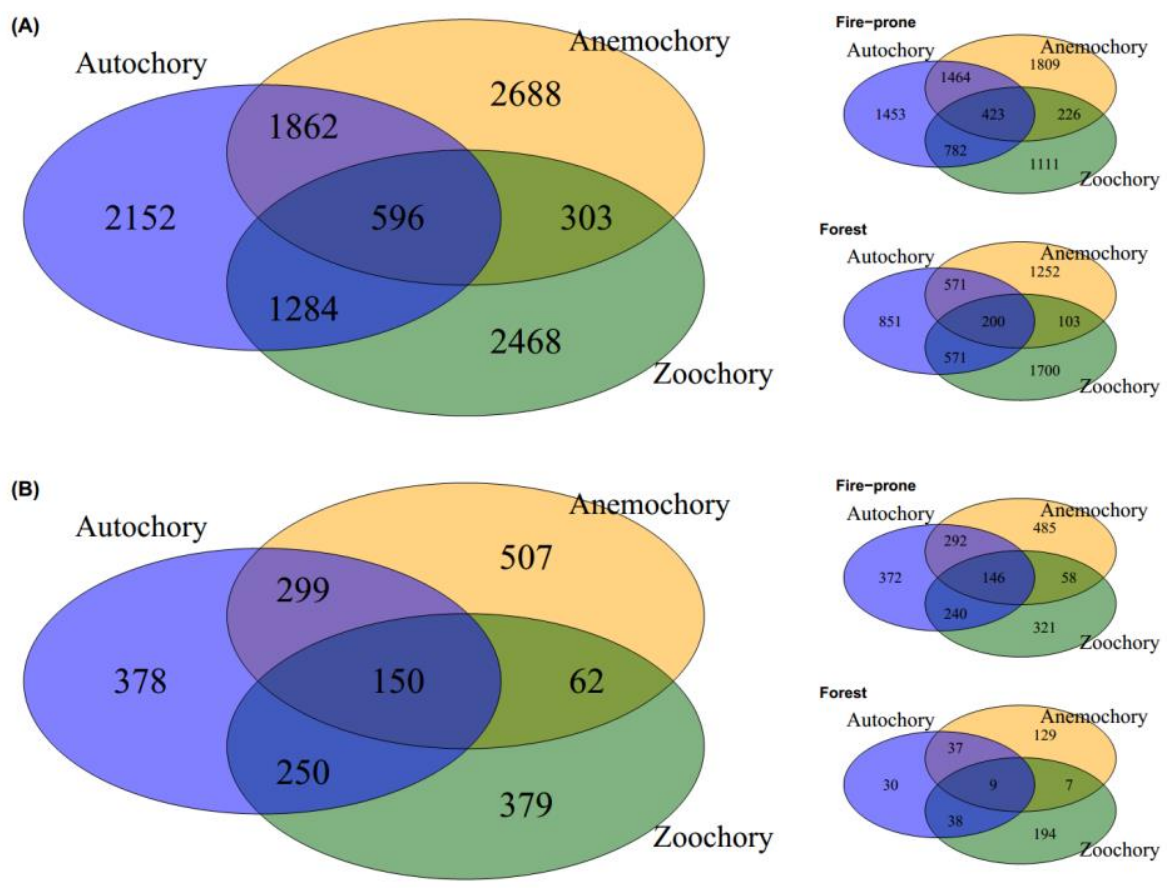

Figure 8. Number of species in each dispersal syndrome in Cerrado biome (A); able to reproduce after fire

921 into dispersal syndromes (B), all of them separated by savanna (fire-prone) and Forest physiognomies.

The dispersal strategy has a direct impact on species abundance, distribution and evolution. When the quality of the environment varies in space and time, like in savannas, there is a selective pressure for increased dispersion (Levin et al. 2003). The dispersion distance is widely different between the dispersal modes; autochory dispersion do not favor long dispersion distance, while the dispersion distance in zoochory is greatest, and wind dispersal syndrome is intermediate (Thomson et al. 2011). Yet, the off-spring dispersal is also influenced by the community structure (density), and it is more obvious in wind dispersed seeds, wherein if there is little physical obstruction imposed by community architecture the seeds could be carried away from the parental plant. In the Cerrado biome, usually after a fire event, there is a simplification of the landscape structure; however the recovery of the structure is farther fast in savanna physiognomies than in

932 Forest, due to the adaptive differences between the physiognomies (see Hoffmann et al. 2003).

933 As the time between plant bloom and plant seed ripening is long for some species (for instance, 934 more than 9 months in Stryphnodendron pumilum, Andira vermifuga and Mimosa foliolosa, A. B. 935 Giroldo personal observation), usually the structure of the community in savanna have been 936 almost recovered (see Rissi 2016), so could not have selective pressure to favor anemochorous 937 species in this physiognomy. Instead of wind-dispersion syndrome, the zoochorous syndrome, 938 that ensure high dispersal distance, was favored there. On the other hand, the forest habitat is 939 not resilient to fire effects (see Hoffmann et al. 2012a; Pellegrini et al. 2015), requiring more time 940 for recovery the community structure, allowing long dispersal distance in species wind-dispersed, that is favored in this physiognomy (Figure 6D). 
943 The density of trees in the Cerrado biome varies greatly between dense and open physiognomies, 944 and fire, together with moisture and soil fertility is the major driver of vegetation type in savannas 945 (Haridasan 2008; Rossatto et al. 2012; Archibald et al. 2013; Lehmann et al. 2014). Many species 946 are dependent on fire to reproduce (Rissi 2016), or, at least, are not inhibited by it (Figure 5A).

947 On the other hand, fire suppression promotes savanna encroachment, with a reduction in 948 biodiversity, mainly in the herbaceous stratum, that is the most species rich (Figure 5B) (BFG 949 2015) and usually photophobic; changes the structure, with the arrival of fire-sensitive species; 950 and modifies the functioning of the Cerrado ecosystem (Durigan \& Ratter 2016). Although, there 951 is not a single recommendation for fire management, the Cerrado biome, as well as others 952 neotropical savannas, needs to implement a fire management policy (Durigan \& Ratter 2016). 953 This ecosystems have a history with fire, which promoted the diversification of many Cerrado 954 lineages (Simon et al. 2009) selecting many traits (Pausas \& Schwilk 2012). Although we were 955 expecting a supremacy of subshrubs against trees in species that were able to reproduce after a 956 fire, we surprisingly discovered that trees are equally qualified and selected to reproduce after a 957 fire event. Trees, like subshrubs, are shaped and selected in fire-prone ecosystems. The 958 persistence of this growth form is ensured by many different traits that could assure their 959 reproduction. Our hypotheses that anemophily and anemochorous species were the syndromes 960 selected in species able to reproduce after a fire was not corroborated. Pollinators enhancement after fire, and the fast recovery of the community structure could be the main causes of the absence of selection pressure in favor of the wind pollination and dispersion syndrome. Many plant families were able to reproduce after a fire, and some of them are good candidates to better study the relations between fire-traits selection and evolution.

\section{References:}

Araújo G.M., Amaral A.F., Bruna E.M., Vasconcelos H.L. (2013). Fire drives the reproductive responses of herbaceous plants in a Neotropical swamp. Plant Ecology, 214, 1479-1484.

Archibald S., Lehmann C.E.R., Gómez-Dans J.L., Bradstock R.A. (2013). Defining pyromes and global syndromes of fire regimes. Proceedings of the National Academy of Sciences, 110, 6442-6447.

Barbosa A.M., Brown J.A., Jimenez-Valverde A., Real R. (2016). modEvA: Model Evaluation and Analysis. R package version 1.2.9/r100, http://R-Forge.R-project.org/projects/modeva/.

Barton N.H., Charlesworth B. (1998). Why Sex and Recombination? Science, 281, 1986-1990.

Batalha M.A., Martins F.R. (2004). Reproductive phenology of the cerrado plant community in Emas National Park (Central Brazil). Australian Journal of Botany, 52, 149-161.

BFG (2015). Growing knowledge: an overview of seed plant diversity in Brazil. Rodriguésia, 66, 2-29.

Bond W.J., Keeley J.E. (2005). Fire as a global 'herbivore': the ecology and evolution of flammable ecosystems. Trends in Ecology \& Evolution, 20, 387-394.

Bond W.J., Midgley J.J. (2001). Ecology of sprouting in woody plants: the persistence niche. Trends in Ecology \& Evolution, 16, 45-51.

Bond W.J., Scott A.C. (2010). Fire and the spread of flowering plants in the Cretaceous. New Phytologist, 188, 1137-1150. 
Campbell J.W., Hanula J.L., Waldrop T.A. (2007). Effects of prescribed fire and fire surrogates on floral visiting insects of the blue ridge province in North Carolina. Biological Conservation, $134,393-404$.

Coutinho L.M. (1982). Ecological effects of fire in Brazilian Cerrado. In: Ecology of Tropical Savannas (eds. Huntley BJ, Walker BH). Springer Berlin, pp. 273-291.

Coutinho L.M. (1990). Fire in the Ecology of the Brazilian Cerrado. In: Fire in the Tropical Biota (ed. Goldammer J). Springer Berlin Heidelberg, pp. 82-105.

Durigan G., Ratter J.A. (2016). The need for a consistent fire policy for Cerrado conservation. Journal of Applied Ecology, 53, 11-15.

Eiten G. (1972). The Cerrado Vegetation of Brazil. Botanical Review, 38, 201-341.

Eiten G. (1978). Delimitation of the Cerrado concept. Vegetatio, 36, 169-178.

Fidelis A., Blanco C. (2014). Does fire induce flowering in Brazilian subtropical grasslands? Applied Vegetation Science, 17, 690-699.

Forest F., Chase M.W. (2009). Eurosid I. In: The timetree of life (eds. Hedges SB, Kumar S). Oxford University Press New York, pp. 188-196.

Forest F., Chase M.W., Persson C., Crane P.R., Hawkins J.A., Conti E. (2007). The role of biotic and abiotic factors in evolution of ant dispersal in the Milkwort family (Polygalaceae). Evolution, 61, 1675-1694.

Fox J., Weisberg S. (2011). An $\{R\}$ Companion to Applied Regression. Second Edition edn. Sage, Thousand Oaks, CA.

García-Nunez C., Azócar A., Silva J.F. (2001). Seed production and soil seed bank in three evergreen woody species from a neotropical savanna. Journal of Tropical Ecology, 17, 563576.

Gottsberger G. (1986). Some pollination strategies in neotropical savannas and forests. Plant Systematics and Evolution, 152, 29-45.

Gottsberger G., Silberbauer-Gottsberger I. (2006a). Life in the Cerrado, a South American Tropical Seasonal Ecosystem: origin, structure, dynamics and plant use. Reta Verlag, England.

Gottsberger G., Silberbauer-Gottsberger I. (2006b). Life in the Cerrado, a South American Tropical Seasonal Ecosystem: pollination and seed dispersal. Reta Verlag, England.

Guisan A., Zimmermann N.E. (2000). Predictive habitat distribution models in ecology. Ecological Modelling, 135, 147-186.

Haridasan M. (2008). Nutritional adaptations of native plants of the cerrado biome in acid soils. Brazilian Journal of Plant Physiology, 20, 183-195.

Hoffmann W.A. (1998). Post-burn reproduction of woody plants in a neotropical savanna: the relative importance of sexual and vegetative reproduction. Journal of Applied Ecology, 35, 422-433.

Hoffmann W.A., Adasme R., Haridasan M., Carvalho M.T., Geiger E.L., Pereira M.A.B., Gotsch S.G., Franco A.C. (2009). Tree topkill, not mortality, governs the dynamics of savanna-forest boundaries under frequent fire in Central Brazil. Ecology, 90, 1326-1337.

Hoffmann W.A., Geiger E.L., Gotsch S.G., Rossatto D.R., Silva L.C.R., Lau O.L., Haridasan M., Franco A.C. (2012a). Ecological thresholds at the savanna-forest boundary: how plant traits, resources and fire govern the distribution of tropical biomes. Ecology Letters, 15, 759-768.

Hoffmann W.A., Jaconis S.Y., McKinley K.L., Geiger E.L., Gotsch S.G., Franco A.C. (2012b). Fuels or microclimate? Understanding the drivers of fire feedbacks at savanna-forest boundaries. Austral Ecology, 37, 634-643.

Hoffmann W.A., Orthen B., Nascimento P.K.V. (2003). Comparative fire ecology of tropical savanna and forest trees. Functional Ecology, 17, 720-726.

Ishara K.L., Maimoni-Rodella R.d.C.S. (2011). Pollination and dispersal systems in a Cerrado remnant (Brazilian Savanna) in Southeastern Brazil. Brazilian Archives of Biology and Technology, 54, 629-642.

Jackman S. (2015). pscl: Classes and Methods for $R$ Developed in the Political Science Computational Laboratory, Stanford University. Department of Political Science, Stanford University. Stanford, California. R package version 1.4.9.

Jacobi C.M., Carmo F.F. (2011). Life-forms, pollination and seed dispersal syndromes in plant communities on ironstone outcrops, SE Brazil. Acta Botanica Brasilica, 25, 395-412.

Just M.G., Hohmann M.G., Hoffmann W.A. (2015). Where fire stops: vegetation structure and microclimate influence fire spread along an ecotonal gradient. Plant Ecology, 1-14.

Keeley J.E., Pausas J.G., Rundel P.W., Bond W.J., Bradstock R.A. (2011). Fire as an evolutionary pressure shaping plant traits. Trends in Plant Science, 16, 406-411. 
Kelly P., Reid N., Davies I. (1997). Effects of experimental burning, defoliation, and pruning on survival and vegetative resprouting in Mistletoes (Amyema miquelii and Amyema pendula). International Journal of Plant Sciences, 158, 856-861.

Lamont B.B., Downes K.S. (2011). Fire-stimulated flowering among resprouters and geophytes in Australia and South Africa. Plant Ecology, 212, 2111-2125.

Lawes M.J., Adie H., Russell-Smith J., Murphy B., Midgley J.J. (2011). How do small savanna trees avoid stem mortality by fire? The roles of stem diameter, height and bark thickness. Ecosphere, 2, 1-13.

Lehmann C.E.R., Anderson T.M., Sankaran M., Higgins S.I., Archibald S., Hoffmann W.A., Hanan N.P., Williams R.J., Fensham R.J., Felfili J., Hutley L.B., Ratnam J., San Jose J., Montes R., Franklin D., Russell-Smith J., Ryan C.M., Durigan G., Hiernaux P., Haidar R., Bowman D.M.J.S., Bond W.J. (2014). Savanna vegetation-fire-climate relationships differ among continents. Science, 343, 548-552.

Levin S.A., Muller-Landau H.C., Nathan R., Chave J. (2003). The ecology and evolution of seed dispersal: a theoretical perspective. Annual Review of Ecology, Evolution, and Systematics, 34, 575-604.

List of Species of the Brazilian Flora (2015). List of Species of the Brazilian Flora, Jardim Botânico do Rio de Janeiro. URL <http://floradobrasil.jbrj.gov.br/>

Maurin O., Davies T.J., Burrows J.E., Daru B.H., Yessoufou K., Muasya A.M., van der Bank M., Bond W.J. (2014). Savanna fire and the origins of the 'underground forests' of Africa. New Phytologist, 204, 201-214.

Miranda H.S., Sato M.N., Andrade S.M.A., Neves B.M.C., Quesada C.A.N., Andrade L.A.Z., Ramos A.E., Medeiros M.B., Santos A.J.B., Silva P.C., Maia J.M.F. (2011). Projeto Fogo. In: Reserva Ecológica do IBGE (ed. Ribeiro ML). Instituto Brasileiro de Geografia e Estatística IBGE Rio de Janeiro - RJ, pp. 162-177.

Munhoz C.B.R., Felfili J.M. (2005). Fenologia do estrato herbáceo-subarbustivo de uma comunidade de campo sujo na Fazenda Água Limpa no Distrito Federal, Brasil. Acta Botanica Brasilica, 19, 979-988.

Ne'eman G., Dafni A., Potss S.G. (2000). The effect of fire on flower visitation rate and fruit set in four core-species in east Mediterranean scrubland. Plant Ecology, 146, 97-104.

Oliveira P.E., Gibbs P.E. (2002). Pollination and reproductive biology in Cerrado plant communities. In: The Cerrados of Brazil: ecology and natural history of a neotropical savanna (eds. Oliveira PS, Marquis RJ). Columbia University Press New York, pp. 329-347.

Otto Sarah P. (2009). The evolutionary enigma of sex. The American Naturalist, 174, S1-S14.

Ozinga W.A., Bekker R.M., Schaminée J.H.J., Van Groenendael J.M. (2004). Dispersal potential in plant communities depends on environmental conditions. Journal of Ecology, 92, 767-777.

Pastore J.F.B., Cavalcanti T.B. (2008). A New Species of Polygala (Polygalaceae) from Brazil. Novon: A Journal for Botanical Nomenclature, 18, 90-93.

Pausas J.G. (2015). Bark thickness and fire regime. Functional Ecology, 29, 315-327.

Pausas J.G., Schwilk D. (2012). Fire and plant evolution. New Phytologist, 193, 301-303.

Pellegrini A.F.A., Hedin L.O., Staver A.C., Govender N. (2015). Fire alters ecosystem carbon and nutrients but not plant nutrient stoichiometry or composition in tropical savanna. Ecology, 96, 1275-1285.

Potts S.G., Vulliamy B., Dafni A., Gidi N.e., O'Toole C., Roberts S., Willmer P. (2003). Response of plant-pollinator communities to fire: changes in diversity, abundance and floral reward structure. Oikos, 101, 103-112.

R Development Core Team (2015). R: a language and environment for statistical computing. In. R Foundation for Statistical Computing Vienna.

Ratter J.A., Bridgewater S., Ribeiro J.F. (2003). Analysis of the floristic composition of the Brazilian Cerrado vegetation III: comparison of the woody vegetation of 376 areas. Edinburgh Journal of Botany, 60, 57-109.

Ribeiro J.F., Walter B.M. (2008). As principais fitofisionomias de Cerrado. In: Cerrado: ecologia e flora (eds. Sano SM, Almeida SP, Ribeiro JF). Embrapa Informação Tecnológica, Embrapa Cerrados Planaltina, DF, pp. 151-212.

Rissi M.N. (2016). Efeito da época da queima na dinâmica de campo sujo de Cerrado. In: Biologia Vegetal. Universidade Estadual Paulista "Júlio de Mesquita Filho" Rio Claro, p. 128.

Rossatto D.R., Silva L.R.C., Villalobos-Vega R., Sternberg L.d.S.L., Franco A.C. (2012). Depth of water uptake in woody plants relates to groundwater level and vegetation structure along a topographic gradient in a neotropical savanna. Environmental and Experimental Botany, 77, 259-266. 
Salazar A., Goldstein G., Franco A., Miralles-Wilhelm F. (2012). Seed limitation of woody plants in Neotropical savannas. Plant Ecology, 213, 273-287.

Simon M.F., Grether R., Queiroz L.P., Skema C., Pennington R.T., Hughes C.E. (2009). Recent assembly of the Cerrado, a neotropical plant diversity hotspot, by in situ evolution of adaptations to fire. Proceedings of the National Academy of Sciences, 106, 20359-20364.

Simon M.F., Pennington T.R. (2012). Evidence for adaptation to fire regimes in the Tropical Savannas of the Brazilian Cerrado. International Journal of Plant Sciences, 173, 711-723.

speciesLink (2015). speciesLink network. URL <http://www.splink.org.br>

Sytsma K.J., Litt A., Zjhra M.L., Pires J.C., Nepokroeff M., Conti E., Walker J., Wilson P.G. (2004). Clades, clocks, and continents: historical and biogeographical analysis of Myrtaceae, Vochysiaceae, and relatives in the Southern Hemisphere. International Journal of Plant Sciences, 165, S85-S105.

Thomson F.J., Moles A.T., Auld T.D., Kingsford R.T. (2011). Seed dispersal distance is more strongly correlated with plant height than with seed mass. Journal of Ecology, 99, 1299-1307.

Van Nuland M.E., Haag E.N., Bryant J.A.M., Read Q.D., Klein R.N., Douglas M.J., Gorman C.E., Greenwell T.D., Busby M.W., Collins J., LeRoy J.T., Schuchmann G., Schweitzer J.A., Bailey J.K. (2013). Fire promotes pollinator visitation: implications for ameliorating declines of pollination services. PLOS ONE, 8, e79853.

Warming E. (1908). Lagoa Santa: contribuição para a geographia phytobiologica. Imprensa Official do Estado de Minas Geraes, Belo Horizonte.

Zizka A., Govender N., Higgins S.I. (2014). How to tell a shrub from a tree: a life-history perspective from a South African savanna. Austral Ecology, 39, 1-12.

Zuur A., leno E.N., Walker S., Saveliev A.A., Smith G.M. (2009). Zero-truncated and zero-inflated models for count data. In: Mixed Effects Models and Extensions in Ecology with R (eds. Zuur A, leno EN, Walker S, Saveliev AA, Smith GM). Springer New York, pp. 261-294. 
1130 Appendix 1. Species able to reproduce after a fire in Brazilian Cerrado with growth form, 1131 physiognomies, pollination and dispersion syndromes, type of fruit and references where the 1132 dispersions syndromes where found.

1133

1134 As data is too large, we attached it in a server. To access it contact the main author.

1135

1136 


\title{
Small plants, great strategies: a complex history about congeneric pairs and grass competition in a Neotropical savanna
}

\author{
Giroldo, A.B. ${ }^{1,2,3}$; Scariot, A. ${ }^{3}$; Ferreira, J.B. ${ }^{1,3}$; Moser, P. ${ }^{1,3}$, Hoffmann, W.A. ${ }^{4}$ \\ 1. Departamento de Ecologia, Universidade de Brasília, Caixa Postal 04457, 70919-970 Brasília, DF, Brazil; \\ 2. Corresponding author: aeltonbg@gmail.com; 3. Embrapa Recursos Genéticos e Biotecnologia, Laboratório de \\ Ecologia e Conservação, Caixa Postal 02372, 70770-900 Brasília, DF, Brazil; 4. Department of Plant and Microbial \\ Biology, North Carolina State University, 2115 Gardner Hall, Box 7612, Raleigh, NC 27695, USA
}

\section{Abstract:}

Competition, facilitation and niche partition drive ecosystem biodiversity and allow the coexistence of multiple growth forms. The models that investigated this coexistence in Neotropical savanna focus primarily in tree-grass coexistence, and although subshrubs and dicot herbs represent more than $50 \%$ of all species, they normally are ignored in coexistence models or incorporated as part of grass stratum. We investigated the effect of grasses in tree and subshrub survival and growth, including the interaction of congeneric pairs of trees and subshrubs, in an experiment split-plot designed. Congeneric pairs are phylogenetic correlated, usually sharing traits that enhance the competitive forces. We found that congeneric pairs competition and grass competition changed growth and survival of the species. Although the effect of grass and congeneric pair competitive forces had been synergetic for tree survival, they were attenuated for trees and subshrubs growth when they were together and no effect was detected. We suggest that trees and subshrubs could establish in savanna by the presence of root gaps. Once the trees are established in these gaps and out of the fire-trap they change the conditions under canopy and facilitate the establishment of new trees. The subshrubs could have an advantage against trees because they can reproduce earlier, and they are more fertile, with more chances to arise in patches with root gap. Yet, the fire frequency plays an important effect in biodiversity, particularly subshrubs, because it avoids savanna encroachment.

Keywords: grass-subshrub-tree, Brazilian Savanna, coexistence, niche partition.

\section{Introduction:}

Competition both intraspecific and interspecific is one of the major forces determining the abundance and distribution of plant species and the plant communities biodiversity (Tilman 2009). The competitive exclusion principle says that even small advantages may result in species exclusion when two species occupy the same niche (Gauze 1934; Hardin 1960). Savannas, that cover $20 \%$ of the world land, are formed by different coexistent growth forms (see Gottsberger \& Silberbauer-Gottsberger 2006; Maurin et al. 2014), some of them are closely related species, usually sharing morphological and physiological traits because of phylogenetic relatedness (Blomberg et al. 2003), which enhances the resource competition. 
Scientific literature has widely demonstrated the process that could reduce the competition in savannas and that mediate tree-grass coexistence (see Scholes \& Archer 1997; Rodríguez-Iturbe et al. 1999; Higgins et al. 2000; Accatino et al. 2010; Dantas et al. 2013; Accatino et al. 2016). In summary, these models highlight that tree-grass coexistence is mediated by fire regime and could be influenced by climate, soil and grazing. Usually, the reduction of fire frequency promotes the savanna encroachment, and the established trees could change the microclimate (Rossatto \& Rigobelo 2016), contributing to avoid fire spread. On the other hand, increased fire frequency could promote grass spread, reducing tree cover in savanna ecosystems (Hoffmann et al. 2012). Although, these models explain very well the tree-grass coexistence, savannas cannot be summarized only by trees and grasses, instead the herbaceous strata (hereafter subshrubs) is the most important element in open habitats, covering the entire ground, with a high richness and density of species (Filgueiras 2002). Current data for the Cerrado indicates that at least 7,654 species are subshrubs and dicots herbs (51\%), excluding 3,380 shrubs, 1,276 vines and 742 grasses species, and trees represent just 1,790 of all species (BFG 2015). Therefore, tree-grass models have incorporated just $19 \%$ of the total biodiversity in savannas, although some models consider subshrubs as part of the grass strata. The incorporation of subshrubs in the same category of grasses could make sense, since $97 \%$ of the herbaceous strata (subshrubs + grasses) is consumed in fire events (Miranda et al. 2002). However, grass, subshrubs and trees differ in some leaf anatomical traits (Rossatto et al. 2015; Díaz et al. 2016) and in some ecophysiological traits related to water access (Nippert \& Knapp 2007; Rossatto et al. 2013), biomass allocation and seed biomass (Díaz et al. 2016). These differences indicate that subshrubs and grasses have different life-history strategies and therefore should be considered as separate units.

Trees and subshrubs when adults could mediate their establishment by facilitation or difficult it by competition. Usually, both growth forms can modify the microclimate and nutritional conditions under canopy (Scholes \& Archer 1997; Rossatto \& Rigobelo 2016), and it has been reported that adult trees can facilitate the establishment of subshrubs (Barnes \& Archer 1999). However once established, they would compete with each other, and when the adult tree dies a new one could not be established under the canopy of subshrubs (Barnes \& Archer 1999). This inhibition of establishment happens because most of the trees are shade intolerant, differently from subshrubs that can tolerate some levels of shade. Although, the literature describes at least the effects of adults in seedling establishment, we do not know the effect of seedling competition of both growth forms. We expected that the growth forms compete with each other because they share common traits since they are phylogenetically correlated, but we do not know who the superior competitor is.

We conducted an experiment to test the effect of grass competition on tree and subshrub establishment and growth. Furthermore, we tested the effect of tree and subshrubs competition, and the combination of their competition with grass competition in a split-plot design experiment. We know that seedling recruitment is a critical life-history stage, mainly for plants with long life 
1213 (Scholes \& Archer 1997; Sankaran et al. 2004), and we had different assumptions for the effect 1214 of grass in trees and subshrubs. First, we hypothesize that the trees and subshrubs seedlings will 1215 not differ against grass competition because the growth forms are very similar in this ontogenetic 1216 stage, and both will be negatively affected. The negative effect would happen because grasses 1217 can reduce the available water, nutrient and photosynthetic active radiation (PAR), as it has been 1218 reported in other studies (Jurena \& Archer 2003; Wardle \& Peltzer 2003; Riginos 2009). The 1219 second hypotheses is that trees are able to grow and develop a deep root system (Kambatuku et 1220 al. 2013), even in the beginning of development (Silveira et al. 2013), so they will be less affected 1221 by grass competition than subshrubs, that compete with grass in the upper soil layers.

\section{Methods:}

\section{- Species selection and experimental design}

1225 We selected three congeneric pairs that represent subshrub and tree growth forms in the Cerrado 1226 biome (Table 1). We used the native grass Paspalum atratum in the experiment, which can be 1227 found in almost all Cerrado biome (Maciel et al. 2009). Grass seeds were obtained from the 1228 Brazilian Agricultural Research Corporation (Embrapa), and seeds of most congeneric pairs were collected in Brasília, Distrito Federal, Brazil. Exceptions were the seeds of C. oblongifolia collected in Chapada Gaúcha, Minas Gerais and A. humile collected in Grão Mogol, Minas Gerais. We collected seeds between November 2013 and July 2014. We sown them in polyethylene bags with $20 \mathrm{~cm}$ diameter and $40 \mathrm{~cm}$ deep. The grass was sown five months before the other species, on February 2014. Separation between plots with and without grass ensured that shadow effect, promoted by grass, occurred just in plots with grass (Figure 1). Stryphnodendron spp. seeds were immersed in sulfuric acid for 5 minutes to break the physical dormancy. We used as substrate $70 \%$ oxisol subsoil (40 $\mathrm{cm}$ deep or more) mixed with $30 \%$ of washed sand, without any other nutrient. The experiment was conducted in a green house, with automatic irrigation system $(\sim 7$ $\mathrm{mm} /$ day). 
Table 1. Species sown in a competition experiment between grass vs subshrub vs tree in Cerrado biome.

\begin{tabular}{llcc}
\hline Family & Species & Growth Form & Habitat \\
\hline Anacardiaceae & Anacardium humile & Subshrub & savanna \\
Anacardiaceae & A. occidentale & Tree & forest/savanna \\
Fabaceae & Stryphnodendron pumilum & Subshrub & savanna \\
Fabaceae & S. adstringens & Tree & forest/savanna \\
Fabaceae & Copaifera oblongifolia & Subshrub & forest/savanna \\
Fabaceae & C. langsdorffii & Tree & forest/savanna \\
Poaceae & Paspalum atratum & Grass & savanna
\end{tabular}

1241 The experiment design was split-plot, with and without grass competition (G+; G-); with and 1242 without congeneric pair competitor ( $\mathrm{C}_{+}$; $\mathrm{C}_{-}$) (Figure 1); and with two growth forms, tree and 1243 subshrubs ( $T$; S). Each species was sown 16 times alone in each plot and together with its 1244 congeneric pair 16 times, in both cases with and without grass.
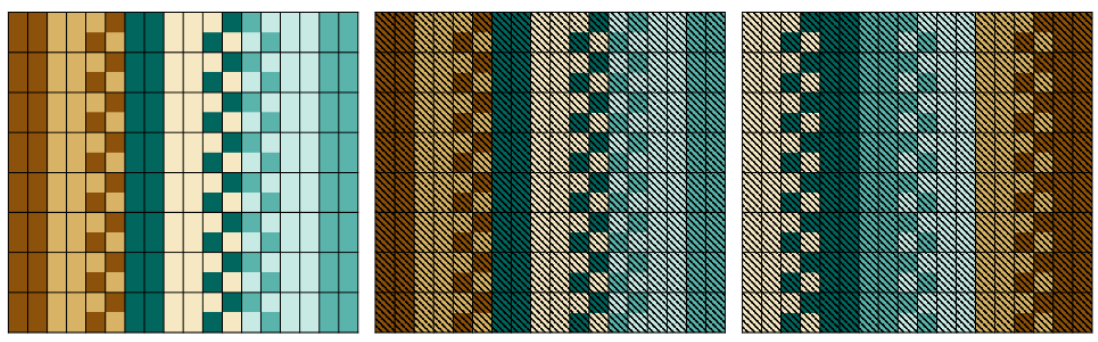

$\square$ Anacardium humile
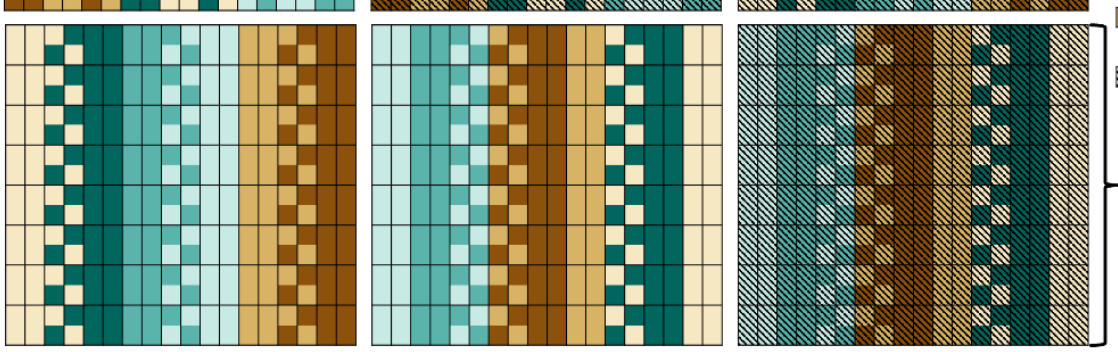

\section{$\square$ A. occidentale}

$\square$ Stryphnodendron pumilum

$\square$ S. adstringens

$\square$ Copaifera oblongifolia

C. langsdorffii

Figure 1. Scheme of competition experiment including six species of trees and subshrubs. Each rectangle represents a bag, colors represent species, and rectangles with mixed colors represent a combination of congeneric pairs. The grass (Paspalum atratum) was sown in three plots.

\section{- Data collection and statistical analysis:}

After one year, we collected the biomass in two bags per plot. The subshrub and tree seedlings were divided in shoot and root part, dried in a dry chamber at $70^{\circ} \mathrm{C}$ per $72 \mathrm{~h}$ (Pérez-Harguindeguy et al. 2013), and weighed in a precision scale $(0.0001 \mathrm{~g})$. After a year and a half, we counted all plants alive in each bag to verify if competition had affected trees and subshrubs survival. We used a linear mixed model to verify if the root:shoot ratio, shoot and root and total plant biomass were different between growth forms ( $\mathrm{S} ; \mathrm{T})$, and were affected by grass $(\mathrm{G}+; \mathrm{G}-)$ or by congeneric pair $\left(\mathrm{C}_{+} ; \mathrm{C}-\right)$ competition. The genus was used as a random factor in the models. To verify if the survival rate was affected by grass and congeneric pair competition, and the difference between 
the growth forms we used a generalized linear mixed model, with a binomial distribution. The genus was used as a random factor. All analyses were done in $\mathrm{R}$ program ( $R$ Development Core Team 2015) using the packages Ime4 (Bates et al. 2015) and car (Fox \& Weisberg 2011).

\section{Results:}

\section{- Survival rate:}

We found that the survival rate was affected by congeneric pair competition $\left(\chi^{2}=11.416, p<\right.$ $0.001)$, but was not affected by grass $\left(\chi^{2}=0.224, p=0.621\right)$, or between growth forms $\left(\chi^{2}=434\right.$, $p=0.510$ ). There was interaction between some factors (Table 1 ), and after exploring them we found that grass competition affected trees survival $\left(\chi^{2}=4.375, p=0.036\right)$, but not subshrubs $\left(\chi^{2}\right.$ $=1.886, p=0.170)$. Yet, the effect of grass just exist together with congeneric pair competition, and only for tree growth form $\left(\chi^{2}=19.700, p<0.001-\right.$ Figure $\left.2 A\right)$.

Table 2. Effect of congeneric competition (CC), grass competition (GC), growth form (GF) on the survival rate and biomass of three congeneric pairs of species from the Brazilian Savanna. Statistic $X^{2}$ is from generalized linear model (GLM) with binomial distribution, and $\mathrm{F}$ is from ANOVA.

\begin{tabular}{lccccc}
\hline Factors & Survival rate & Plant Total Biomass & Root Biomass & Shoot Biomass & Shoot:Root Ratio \\
\hline GC & $X^{2}=0.224$ & $F_{1,118}=21.557^{* *}$ & $F_{1,119}=20.232^{* * *}$ & $F_{1,116}=13.755^{\star * *}$ & $F_{1,116}=4.223^{*}$ \\
CC & $X^{2}=11.416^{\star * *}$ & $F_{1,118}=4.323^{*}$ & $F_{1,119}=5.725^{*}$ & $F_{1,116}=1.036$ & $F_{1,116}=1.351$ \\
GF & $X^{2}=0.434$ & $F_{1,2}=0.489$ & $F_{1,2}=2.362$ & $F_{1,2}=0.535$ & $F_{1,2}=0.891$ \\
GC:CC & $X^{2}=4.033^{*}$ & $F_{1,118}=9.748^{* *}$ & $F_{1,119}=8.162^{* *}$ & $F_{1,116}=8.423^{\star *}$ & $F_{1,116}=0.836$ \\
GC:GF & $X^{2}=6.214^{*}$ & $F_{1,120}=0.136$ & $F_{1,120}=0.001$ & $F_{1,116}=0.770$ & $F_{1,116}=3.711$ \\
CC:GF & $X^{2}=0.578$ & $F_{1,120}=6.551^{*}$ & $F_{1,120}=4.921^{*}$ & $F_{1,116}=2.960$ & $F_{1,116}=1.857$ \\
GC:CC:GF & $X^{2}=6.406^{*}$ & $F_{1,116}=0.031$ & $F_{1,116}=0.017$ & $F_{1,117}=0.358$ & $F_{1,117}=0.745$
\end{tabular}

1275 Significance statistical values: ${ }^{*} p \leq 0.05$; ${ }^{* *} p \leq 0.01 ;{ }^{* * *} p \leq 0.001$.

1277 Grass and congeneric pairs competition affected negatively the plant biomass in almost all the 1278 factors analyzed (Table 2 - Figure 2B-E), and there were interactions between the congeneric 1279 pairs and grass competition, and between congeneric pairs competition and growth forms. 1280 Congeneric pair competition affected subshrubs plant total biomass $\left(F_{1,60}=10.455, p=0.002\right)$ 1281 and root biomass $\left(F_{1,60}=10.996, p=0.001\right)$, but not the tree plant biomass $\left(F_{1,60}=0.135, p=\right.$ $12820.714)$ or tree root biomass $\left(F_{1,60}=0.001, p=0.999\right)$. Moreover, the negative effect of grass and congeneric pair competition just occurred when applied alone. When grass competition was analised as a treatment the congeneric pair competition did not affect plant total biomass $\left(F_{1,52}=\right.$ $12850.120, p=0.731)$, root biomass $\left(F_{1,53}=0.399, p=0.530\right)$ or shoot biomass $\left(F_{1,52}=0.115, p=\right.$ $0.735)$. The inverse was equally true, when the congeneric pair competition was present the grass 1287 did not exert any effect on plant total biomass $\left(F_{1,54}=0.266, p=0.608\right)$, root plant biomass $\left(F_{1,47}\right.$ $=0.015, p=0.903)$ or shoot biomass $\left(F_{1,52}=0.036, p=0.850\right)$ (Figure $2 B-D$ ). 

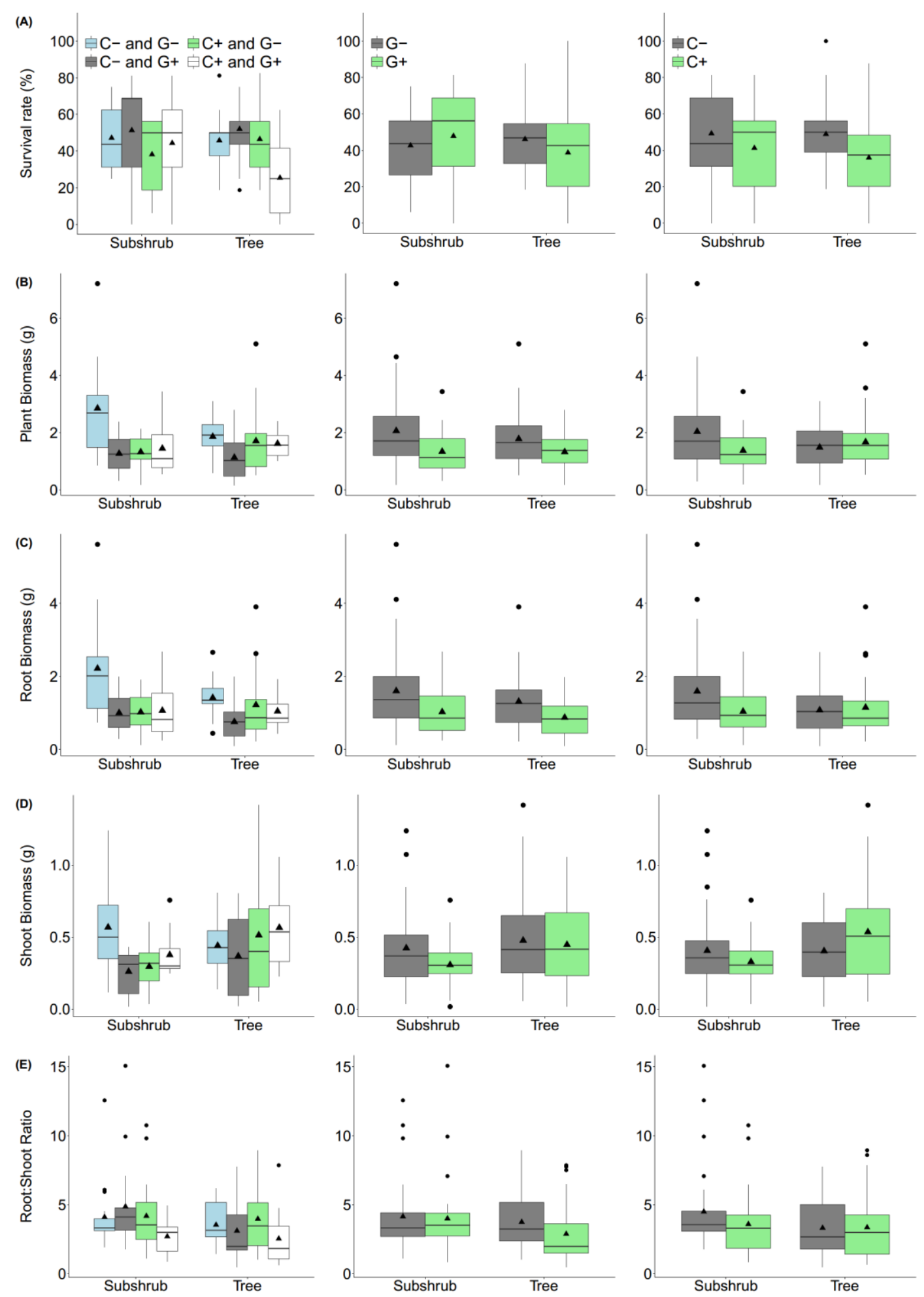

1291 Figure 2. A) Survival rate, B) Plant Biomass, C) Root Biomass, D) Shoot Biomass and E) Shoot:Root ratio of subshrubs and trees separated by grass competition (presence - $G_{+}$, absent - G-), and congeneric pair competition (presence - $\mathrm{C}_{+}$, absent - C-). The box plots indicate median, quartiles, and data range. Dots denote outliers and triangles means. 


\section{Discussion:}

Coexistence of multiple growth forms in savannas is possible by a combination of niche segregation, intra and inter growth forms competition, asymmetry of competition and frequent disturbance, particularly fire (Scholes \& Archer 1997; Rossatto et al. 2015; Accatino et al. 2016). Yet, the multiple competitive forces carried out by a mix of species can attenuate the intensity that exist in pairwise competition, and ensure the coexistence (Aschehoug \& Callaway 2015). The attenuated effect seems to happen in our study when the competitive negative effect of grass inhibits the effect of congeneric pair competition, and vice-versa, in plant biomass (Figure 2B-D). Oppositely, the effect of both competitive factors seems to be synergetic when related with tree survival (Figure 2A).

The grass competition reduced trees and subshrubs growth (Figure 2), probably because grass cover can reduce light, water and nutrient resources availability (Scholes \& Archer 1997). The reduction in biomass allocation pattern can result in a lower resources exploration by both growth forms (Wardle \& Peltzer 2003), and consequently reduce root reserves content, that is necessary to survive after perturbation, and root depth, mainly in trees, that is a requirement to extract water in depth soil during the dry season. Although grass competition can decrease the chance of establishment and growth of both growth forms, this effect is probably not strong enough to generate total competitive exclusion (Scholes \& Archer 1997). We believe that the coexistence of multiple growth forms in savannas could be ensured by environmental heterogeneity and ecophysiological differences that exist between growth forms.

As tree survival is negatively affected by a synergic effect of congeneric pairs and grass competition, and growth better in the presence of both together, but not in the presence of one or another, the tree life-history is complex and the tree establishment is dependent on root gaps at least in the beginning of development. The root gap hypothesis postulates that the absence of grass roots in patches within the landscape is ensured by environmental heterogeneity. In these patches trees could be able to establishment and grow normally (Cramer et al. 2012; Wakeling et al. 2015). The formation of root gaps is related with a reduction in fire frequency and intensity, that is related with rainfall, grazing and animal trampling (Van Langevelde et al. 2003; Bond \& Keeley 2005; Accatino et al. 2010; Koerner \& Collins 2014). Once the tree is established and can escape from the fire-trap (see Wakeling et al. 2011; Dantas \& Pausas 2013), it can alter the conditions under canopy, allowing the establishment of more trees and the savanna encroachment (Scholes \& Archer 1997; Accatino et al. 2016; Rossatto \& Rigobelo 2016).

Subshrub survival and growth are mitigated when both grass and tree competition are together (Figure 2), however when alone with the tree congeneric pair the subshrubs lose the competition and grow less. The negatively competitive effect of trees against subshrubs could explain why the subshrubs are less abundant in forest than in savanna ecosystems (BFG 2015), since in forests the grasses are not present, and against trees they are inferior competitors. Yet, the root gap hypotheses could explain the establishment of subshrubs in savannas, with the advantage that this growth form has high fertility (Westoby et al. 2002), since their seeds are smaller (Díaz et al. 2016), that allow them to reach more patches than trees. Subshrubs are also able to 
reproduce early (Zizka et al. 2014), and can colonize patches were trees and grasses were present together, enhancing their fitness in neotropical savanna.

The Neotropical savanna burn, on average, once every five years (Gottsberger \& SilberbauerGottsberger 2006), and the main effect of this fire frequency is the absence of savanna encroachment, with an abundant grass layer, and scattered trees in the landscape (Bond \& Keeley 2005; Bond 2008). This type of landscape is able to keep biodiversity, indicating how fire regime is important to maintain the biodiversity, mainly subshrubs, in savannas. If fire frequency is reduced, probably the trees abundance will increase, and consequently, as trees are able to suppress the grass development, the subshrubs will be reduced, as they are inferior competitors in a pairwise relation with trees. In conclusion, the mitigated effect of multiple competitive forces, together with fire regime are able to keep biodiversity in Neotropical savanna, and if natural areas are not correctly fire managed, the biodiversity could be reduced.

\section{References:}

Accatino F., De Michele C., Vezzoli R., Donzelli D., Scholes R.J. (2010). Tree-grass coexistence in savanna: interactions of rain and fire. Journal of Theoretical Biology, 267, 235242.

Accatino F., Wiegand K., Ward D., De Michele C. (2016). Trees, grass, and fire in humid savannas-The importance of life history traits and spatial processes. Ecological Modelling, 320, 135-144.

Aschehoug E.T., Callaway R.M. (2015). Diversity increases indirect interactions, attenuates the intensity of competition, and promotes coexistence. The American Naturalist, 186, 452-459.

Barnes P.W., Archer S. (1999). Tree-Shrub Interactions in a Subtropical Savanna Parkland: Competition or Facilitation? Journal of Vegetation Science, 10, 525-536.

Bates D., Maechler M., Bolker B., Walker S. (2015). Fitting linear mixed-effects models using Ime4. Journal of Statistical Software, 1-51.

BFG (2015). Growing knowledge: an overview of seed plant diversity in Brazil. Rodriguésia, 66, 2-29.

Blomberg S.P., Garland T., Ives A.R. (2003). Testing for phylogenetic signal in comparative data: behavioral traits are more labile. Evolution, 57, 717-745.

Bond W.J. (2008). What Limits Trees in C4 Grasslands and Savannas? Annual Review of Ecology, Evolution, and Systematics, 39, 641-659.

Bond W.J., Keeley J.E. (2005). Fire as a global 'herbivore': the ecology and evolution of flammable ecosystems. Trends in Ecology \& Evolution, 20, 387-394.

Cramer M.D., Wakeling J.L., Bond W.J. (2012). Belowground competitive suppression of seedling growth by grass in an African savanna. Plant Ecology, 213, 1655-1666.

Dantas V.L., Batalha M.A., Pausas J.G. (2013). Fire drives functional thresholds on the savanna-forest transition. Ecology, 94, 2454-2463.

Dantas V.L., Pausas J.G. (2013). The lanky and the corky: fire-escape strategies in savanna woody species. Journal of Ecology, 101, 1265-1272.

Díaz S., Kattge J., Cornelissen J.H.C., Wright I.J., Lavorel S., Dray S., Reu B., Kleyer M., Wirth C., Colin Prentice I., Garnier E., Bönisch G., Westoby M., Poorter H., Reich P.B., Moles A.T., Dickie J., Gillison A.N., Zanne A.E., Chave J., Joseph Wright S., Sheremet'ev S.N., Jactel H., Baraloto C., Cerabolini B., Pierce S., Shipley B., Kirkup D., Casanoves F., Joswig J.S., Günther A., Falczuk V., Rüger N., Mahecha M.D., Gorné L.D. (2016). The global spectrum of plant form and function. Nature, 529, 167-171.

Filgueiras T.S. (2002). Herbaceous plant communities. In: The Cerrados of Brazil: ecology and natural history of a neotropical savanna (eds. Oliveira PS, Marquis RJ). Columbia University Press New York, pp. 121-139.

Fox J., Weisberg S. (2011). An $\{R\}$ Companion to Applied Regression. Second Edition edn. Sage, Thousand Oaks, CA.

Gauze G.F. (1934). The Struggle for Existence. The Williams \& Wilkins company, Baltimore. 
Gottsberger G., Silberbauer-Gottsberger I. (2006). Life in the Cerrado, a South American Tropical Seasonal Ecosystem: origin, structure, dynamics and plant use. Reta Verlag, England.

Hardin G. (1960). The competitive exclusion principle. Science, 131, 1292-1297.

Higgins S.I., Bond W.J., Winston S.W.T. (2000). Fire, resprouting and variability: a recipe for grass-tree coexistence in Savanna. Journal of Ecology, 88, 213-229.

Hoffmann W.A., Jaconis S.Y., McKinley K.L., Geiger E.L., Gotsch S.G., Franco A.C. (2012). Fuels or microclimate? Understanding the drivers of fire feedbacks at savanna-forest boundaries. Austral Ecology, 37, 634-643.

Jurena P.N., Archer S. (2003). Woody plant establishment and spatial heterogeneity in grasslands. Ecology, 84, 907-919.

Kambatuku J.R., Cramer M.D., Ward D. (2013). Overlap in soil water sources of savanna woody seedlings and grasses. Ecohydrology, 6, 464-473.

Koerner S.E., Collins S.L. (2014). Interactive effects of grazing, drought, and fire on grassland plant communities in North America and South Africa. Ecology, 95, 98-109.

Maciel J.R., Oliveira R.C.d., Alves M. (2009). Padrões de distribuição das espécies de Paspalum L. (Poaceae: Panicoideae: Paniceae) ocorrentes em Pernambuco, Brasil. Brazilian Journal of Botany, 32, 597-605.

Maurin O., Davies T.J., Burrows J.E., Daru B.H., Yessoufou K., Muasya A.M., van der Bank M., Bond W.J. (2014). Savanna fire and the origins of the 'underground forests' of Africa. New Phytologist, 204, 201-214.

Miranda H.S., Bustamante M.M.C., Miranda A.C. (2002). The fire factor. In: The Cerrados of Brazil: ecology and natural history of a neotropical savanna (eds. Oliveira PS, Marquis RJ). Columbia University Press New York, pp. 51-68.

Nippert J.B., Knapp A.K. (2007). Linking water uptake with rooting patterns in grassland species. Oecologia, 153, 261-272.

Pérez-Harguindeguy N., Díaz S., Garnier E., Lavorel S., Poorter H., Jaureguiberry P., BretHarte M.S., Cornwell W.K., Craine J.M., Gurvich D.E., Urcelay C., Veneklaas E.J., Reich P.B., Poorter L., Wright I.J., Ray P., Enrico L., Pausas J.G., de Vos A.C., Buchmann N., Funes G., Quétier F., Hodgson J.G., Thompson K., Morgan H.D., ter Steege H., van der Heijden M.G.A., Sack L., Blonder B., Poschlod P., Vaieretti M.V., Conti G., Staver A.C., Aquino S., Cornelissen J.H.C. (2013). New handbook for standardised measurement of plant functional traits worldwide. Australian Journal of Botany, 61, 167-234.

R Development Core Team (2015). R: a language and environment for statistical computing. In. R Foundation for Statistical Computing Vienna.

Riginos C. (2009). Grass competition suppresses savanna tree growth across multiple demographic stages. Ecology, 90, 335-340.

Rodríguez-Iturbe I., D'Odorico P., Porporato A., Ridolfi L. (1999). Tree-grass coexistence in Savannas: The role of spatial dynamics and climate fluctuations. Geophysical Research Letters, 26, 247-250.

Rossatto D.R., Kolb R.M., Franco A.C. (2015). Leaf anatomy is associated with the type of growth form in Neotropical savanna plants. Botany, 93, 507-518.

Rossatto D.R., Rigobelo E.C. (2016). Tree encroachment into savannas alters soil microbiological and chemical properties facilitating forest expansion. Journal of Forestry Research, 1-8.

Rossatto D.R., Sternberg L.S.L., Franco A.C. (2013). The partitioning of water uptake between growth forms in a Neotropical savanna: do herbs exploit a third water source niche? Plant Biology, 15, 84-92.

Sankaran M., Ratnam J., Hanan N.P. (2004). Tree-grass coexistence in savannas revisited insights from an examination of assumptions and mechanisms invoked in existing models. Ecology Letters, 7, 480-490.

Scholes R.J., Archer S.R. (1997). Tree-Grass Interactions in Savannas. Annual Review of Ecology and Systematics, 28, 517-544.

Silveira C.E.S., Palhares D., Pereira L.A.R., Pereira K.B.D., Silva F.A.B. (2013). Strategies of plant establishment of two Cerrado species: Byrsonima basiloba Juss. (Malpighiaceae) and Eugenia dysenterica Mart. ex DC (Myrtaceae). Plant Species Biology, 28, 130-137.

Tilman, D. 2009. Mechanisms of Plant Competition. Pages 239-261 in M. Crawley, editor. Plant Ecology. Blackwell Publishing Ltd., New York.

Van Langevelde F., Van De Vijver C.A.D.M., Kumar L., Van De Koppel J., De Ridder N., Van Andel J., Skidmore A.K., Hearne J.W., Stroosnijder L., Bond W.J., Prins H.H.T., Rietkerk M. 
(2003). Effects of fire and herbivory on the stability of savanna ecosystems. Ecology, 84, 337-350.

Wakeling J.L., Bond W.J., Ghaui M., February E.C. (2015). Grass competition and the savannagrassland 'treeline': A question of root gaps? South African Journal of Botany, 101, 91-97.

Wakeling J.L., Staver A.C., Bond W.J. (2011). Simply the best: the transition of savanna saplings to trees. Oikos, 120, 1448-1451.

Wardle D.A., Peltzer D.A. (2003). Interspecific interactions and biomass allocation among grassland plant species. Oikos, 100, 497-506.

Westoby M., Falster D.S., Moles A.T., Vesk P.A., Wright I.J. (2002). Plant ecological strategies: some leading dimensions of variation between species. Annual Review of Ecology and Systematics, 33, 125-159.

Zizka A., Govender N., Higgins S.I. (2014). How to tell a shrub from a tree: a life-history perspective from a South African savanna. Austral Ecology, 39, 1-12. 


\section{Conclusão Geral}

1461 O principal motivo da realização deste estudo foi verificar os motivos das pequenas plantas, ervas

1462 e subarbustos serem tão abundantes no ambiente savânico. No primeiro capítulo foram 1463 investigadas as diferenças nas características de peso de semente, taxa de germinação, taxa de 1464 sobrevivência, taxa de fotossíntese e respiração, área foliar especifica, capacidade de rebrota e 1465 alocação de biomassa. Essas características foram investigadas com o intuído de se testar a 1466 hipótese de que as espécies de subarbusto representariam o ponto final da história evolutiva no 1467 bioma Cerrado, possuindo menor área foliar específica, maior investimento em raízes e reservas, 1468 e maior capacidade de rebrota. Embora árvores e subarbustos sejam muito diferentes quando 1469 adultos, surpreendentemente a maioria destas características são semelhantes entre plântulas 1470 de subarbustos e árvores. Entretanto acredita-se que as pequenas diferenças encontradas na 1471 alocação de biomassa e peso de sementes possam resultar, com o tempo, em grandes 1472 diferenças nas histórias de vida de subarbustos e árvores.

1473 No segundo capítulo, foram investigadas as plantas capazes de se reproduzir após o fogo, 1474 incluindo as diferenças entre as formas de vida e as síndromes de polinização ou dispersão. Os 1475 resultados não corroboraram as hipóteses levantadas de que subarbustos seriam as espécies 1476 mais favorecidas em reprodução após o fogo, ou mesmo que as síndromes de polinização e 1477 dispersão por vento ocorreriam mais frequentemente após o fogo. Foram encontradas 2.058 1478 espécies, distribuídas em mais de 111 famílias, capazes de se reproduzir após o fogo, sendo $147960 \%$ delas subarbustos. As árvores tiveram uma razão de chance de se reproduzir maior do que 1480 o esperado ao acaso, razão essa superior à dos subarbustos, embora não significativamente 1481 diferente. No que se refere à polinização, novamente os resultados não corroboraram as 1482 hipóteses estabelecidas, e nenhuma síndrome foi favorecida em plantas que se reproduzem 1483 após o fogo. Provavelmente, o não favorecimento de nenhuma síndrome de polinização ocorre 1484 devido a um aumento dos dispersores, o que não gera pressão de seleção a favor de uma ou 1485 outra síndrome. A rápida recuperação da estrutura das formações savânicas após a passagem 1486 de fogo indica que há baixa pressão de seleção em favor da dispersão anemocórica.

1487 No último capítulo foram testadas hipóteses nas quais subarbustos e árvores diferiam quanto a 1488 capacidade competitiva contra o estrato graminoso. Além disso, uma hipótese alternativa era de 1489 que as duas formas de vida eram igualmente afetadas pela grama. Também se testou o efeito 1490 da competição de subarbustos contra gramas, e a interação gramas e presença de outra forma 1491 de vida. Os resultados indicam que não há simetria entre a competição exercida entre 1492 subarbustos e árvores. Árvores exercem efeito negativo em subarbustos, mas o inverso não 1493 ocorre. Gramíneas influenciam negativamente as duas formas de vida, mas a competição 1494 exercida sobre os subarbustos é atenuada pela presença concomitante de gramíneas e árvores. 1495 Em árvores, o efeito competitivo não é atenuado, ao contrário, subarbustos e gramíneas atuam 1496 de forma sinérgica e reduzem o estabelecimento das árvores. Desta forma, o estabelecimento 1497 de árvores é dependente de "root gaps" e o de subarbustos poderia ocorrer tanto nos "root gaps" 1498 quanto na presença de árvores com gramíneas. 
1499 A síntese destes três capítulos fomenta a hipótese de que a diferença encontrada na abundância 1500 de subarbustos em relação às árvores poderia se dar pelas diferenças nas características de 1501 alocação de reservas, o que poderia conferir uma maior chance de sobrevivência em eventos 1502 sucessivos de fogo, ou na escassez de nutrientes. Além disso, o próprio peso das sementes 1503 poderia resultar em aumento de "fitness" por parte das plantas menores, uma vez que uma 1504 semente menor seria facilmente enterrada, e, portanto, menos predada e susceptível ao fogo. 1505 Embora possa parecer que existem diferenças nas chances reprodutivas de subarbustos e 1506 árvores, ambas as formas de vida são igualmente capazes de se reproduzir após o fogo. 1507 Acredita-se que a aquisição precoce da capacidade reprodutiva de espécies subarbustivas possa 1508 garantir um maior "fitness" em ambientes pirofíticos, e a demora em atingir o tamanho reprodutivo 1509 por parte das árvores acaba por ser um limitante à proliferação sexuada dessa forma de vida. 1510 Além disso, as formas arbóreas teriam maior chance de se estabelecer em locais onde há a 1511 presença de "root gaps", reduzindo assim as oportunidade de estabelecimento das mesmas, 1512 enquanto as formas subarbustivas se estabeleceriam na presença de gramíneas e árvores.

1513 As adaptações apresentadas pelas diferentes formas de vida ao ambiente pirofítico demonstram 1514 a importância do fogo como modelador das comunidades. A grande quantidade de espécies 1515 capazes de se reproduzir, distribuídas em diferentes famílias e formas de vida, mostra que além 1516 das características que favorecem a sobrevivência, as características reprodutivas poderiam ser 1517 vistas como uma características que favorece a persistência em ambientes pirofíticos. 